\title{
Atmospheric Dynamics from Synoptic to Local Scale During an Intense Frontal Dust Storm over the Sistan Basin in Winter 2019
}

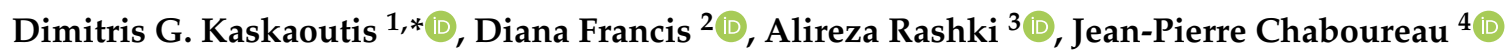 \\ and Umesh C. Dumka ${ }^{5}$ \\ 1 Institute for Environmental Research and Sustainable Development, National Observatory of Athens, \\ 15236 Athens, Greece \\ 2 NYUAD Institute, New York University Abu Dhabi, Abu Dhabi 129188, UAE; diana.francis@nyu.edu \\ 3 Department of Desert and Arid zones management, Ferdowsi University of Mashhad, Mashhad 91735, Iran; \\ arrashki@gmail.com \\ 4 Laboratoire d'Aérologie, Université de Toulouse, CNRS, UPS, 31400 Toulouse, France; \\ Jean-Pierre.Chaboureau@aero.obs-mip.fr \\ 5 Aryabhatta Research Institute of Observational Sciences, Nainital 263 001, India; dumka@aries.res.in \\ * Correspondence: dkask@noa.gr
}

Received: 1 October 2019; Accepted: 21 October 2019; Published: 22 October 2019

\begin{abstract}
The Sistan Basin has been recognized as one of the most active dust sources and windiest desert environments in the world. Although the dust activity in Sistan maximizes during the summer, rare but intense dust storms may also occur in the winter. This study aims to elucidate the atmospheric dynamics related to dust emission and transport, dust-plume characteristics, and impacts on aerosol properties and air quality during an intense dust storm over Sistan in February 2019. The dust storm was initiated by strong northerly winds $\left(\sim 20 \mathrm{~ms}^{-1}\right)$ associated with the intrusion of a cold front from high latitudes. The upper-level potential vorticity (PV)-trough evolved into a cut-off low in the mid and upper troposphere and initiated unstable weather over Afghanistan and northern Pakistan. At the surface, density currents emanating from deep convective clouds and further strengthened by downslope winds from the mountains, caused massive soil erosion. The passage of the cold front reduced the temperature by $\sim 10{ }^{\circ} \mathrm{C}$ and increased the atmospheric pressure by $\sim 10 \mathrm{hPa}$, while the visibility was limited to less than $200 \mathrm{~m}$. The rough topography played a major role in modulating the atmospheric dynamics, wind field, dust emissions, and transport pathways. Meso-NH model simulates large amounts of columnar mass dust loading $\left(>20 \mathrm{~g} \mathrm{~m}^{-2}\right)$ over Sistan, while the intense dust plume was mainly traveling below $2 \mathrm{~km}$ and increased the particulate matter $\left(\mathrm{PM}_{10}\right)$ concentrations up to $1800 \mu \mathrm{g} \mathrm{m}^{-3}$ at Zabol. The dust storm was initially moving in an arc-shaped pathway over the Sistan Basin and then it spread away. Plumes of dust covered a large area in southwest Asia, reaching the northern Arabian Sea, and the Thar desert one to two days later, while they strongly affected the aerosol properties at Karachi, Pakistan, by increasing the aerosol optical depth (AOD > 1.2) and the coarse-mode fraction at $\sim 0.7$.
\end{abstract}

Keywords: frontal dust storm; upper-level trough; cut-off low; dust aerosols; Sistan

\section{Introduction}

Sand and dust storms are the result of strong, turbulent near-surface winds over arid and semi-arid areas, entraining large quantities of fine-grained soil particles into the atmosphere and transporting them thousands of kilometers downwind [1-4]. Dust storms have significant impacts on the whole Earth-atmosphere system, as they modify the atmospheric chemical composition (e.g., [5-7]), affect 
the radiation-energy budget (e.g., [8,9]), contribute to the acceleration of glacier melting (e.g., [10]), desertification, and land degradation by loss of topsoil (e.g., [11,12]), modify cloud microphysical properties and weather (e.g., $[13,14])$, and adversely impact ecosystems (e.g., $[15,16])$ and human health (e.g., [17-19]).

Nowadays, satellite remote sensing of various temporal and spatial resolutions constitutes the best tool for monitoring three-dimensional (3D) dust characteristics [20,21]. Atmospheric models are increasingly available for simulations of dust characteristics, emission rates, uplift dynamics, and dust impact on radiative forcing and climate (e.g., [22-24]). Ground-based measurements at meteorological/atmospheric stations provide useful information about dust-aerosol characteristics via sun photometers and lidar systems (e.g., [25,26]), as well as visibility observations (e.g., [27-29]). Apart from the Sahara, the Middle East and southwest Asia emit large quantities of dust mainly in summer [30], while some rare but intense dust storms may also occur during winter (e.g., [31,32]). Dust storms in the Middle East and southwest Asia are usually associated with enhanced pressure gradients initiating intense northerly winds able to emit and transport dust plumes hundreds of kilometers downwind [33-36]. The topography modulates the main flow via channeling effects $[37,38]$ and by accelerating the downslope winds [39]. Furthermore, mountains in arid areas can trigger deep convection under certain conditions. The convectively-generated density currents that emanate from the developing clouds can then trigger dust emissions $[30,40,41]$. These phenomena are not well studied over Sistan due to the lack of sufficient observational network and lack of high-resolution modeling studies [42,43].

The Sistan Basin, located on the borders of southeast Iran and southwest Afghanistan, is an enclosed topographic-low drainage basin, which was recognized as one of the most active dust sources in Asia and one of the windiest arid environments over the globe [38,44-46]. Sand and dust storms constitute a particularly significant environmental health concern for people living in the Sistan Basin via various hazards to ecosystems, human health, and societal habits [47,48]. Dust activity in Sistan has been demonstrated to have a strong linkage with the inter-annual to intra-seasonal changes in water coverage of the ephemeral Hamoun Lake and greenery of the area [49], as well as to synoptic meteorology via changes in teleconnection patterns and CasHKI (Caspian Sea Hindu Kush Index) intensity [34,50]. Presence of saline dust storms due to Aeolian deflation from salt-rich sediments and salinized soils are often observed in the Sistan Basin [51,52]. Gale winds, especially during the summer season, are responsible for fine-sand emissions from the exposed dried-lake beds which are deposited as huge sand dunes over the whole Sistan Basin [53,54]. Dust storms that originate from Sistan may extend as far as southwest Pakistan, northern Arabian Sea, Indus Basin, and northwest India [55-57], constituting an important factor for the local/regional climate system.

The present study focuses on examining the atmospheric circulation patterns and the dynamic processes, from local to regional scales, that facilitated an intense dust storm over the Sistan Basin on 6-7 February 2019. Despite several previous works focusing on meteorology and dust-related events over Sistan, this study is the first that examines a wintertime dust storm during a period with rare dust activity over this region. It elucidates the mechanisms at the origin of dust emissions, uplift and transport at various spatial and temporal scales via synergy of reanalysis, model simulations, satellite and ground-based observations. The impact of the long-range transported dust plume on aerosol properties in the megacity of Karachi is examined via Aerosol Robotic Network (AERONET) retrievals. After exposing the study area in Section 2, we describe the datasets and the model simulations used in this study in Section 3. The dust storm characteristics and the atmospheric dynamics generating emissions and facilitating the long-range transport of dust are analyzed in Section 4. Concluding remarks are summarized in Section 5.

\section{Study Area}

The Sistan Basin is an interior topographic-low basin on the borders of Iran and Afghanistan (Figure 1a). This region lies at $29^{\circ}-31.5^{\circ} \mathrm{N}$ to $61^{\circ}-66^{\circ} \mathrm{E}$ and is characterized by a complex topography 
with mountains up to $\sim 4 \mathrm{~km}$, large desert plateaus, and deep valleys with relatively low population density. The basin includes a drainage depression (Hamouns), which is fed from the Helmand River and its tributaries, the Margo and Registan Deserts. The Hamoun Lake system is surrounded by arid and rocky mountains to the north and west, while towards the south and east, alluvial playas of the Helmand River discharge dominate. The elevation of the plateau ranges from $\sim 480 \mathrm{~m}$ in the Hamoun Lake to $\sim 1200 \mathrm{~m}$ in the eastern parts of the Registan Desert [58,59]. Sentinel imagery with different band combinations on 7 February 2017 (Figure S1) reveals the near dryness of Hamoun Lake, apart from a very small water area in Hamoun Saburi, and limited greenery of the surrounding areas, which made the surface very rich in deflatable material. Sentinel imagery also shows a large difference in the soil color and, therefore, mineralogical composition, between Hamoun Lake and the surrounding desert areas (Registan, Margo), attributed to the saline silt and clay soils in Hamoun. In contrast, Registan and Margo Deserts are mostly composed by aeolian sand, lacustrine silt, and coarse gravels (Figure S2), giving a pale and more reddish (or grey) color (Figure S1). The geology in the Sistan Basin is mainly characterized by aeolian sand, Quaternary lacustrine silt, and clay materials, Holocene and Neogene fluvial sand (Figure S2 and British Geological Survey; http://bgs.ac.uk/). More details about the geology and mineralogy of the basin can be found elsewhere $[58,60,61]$.
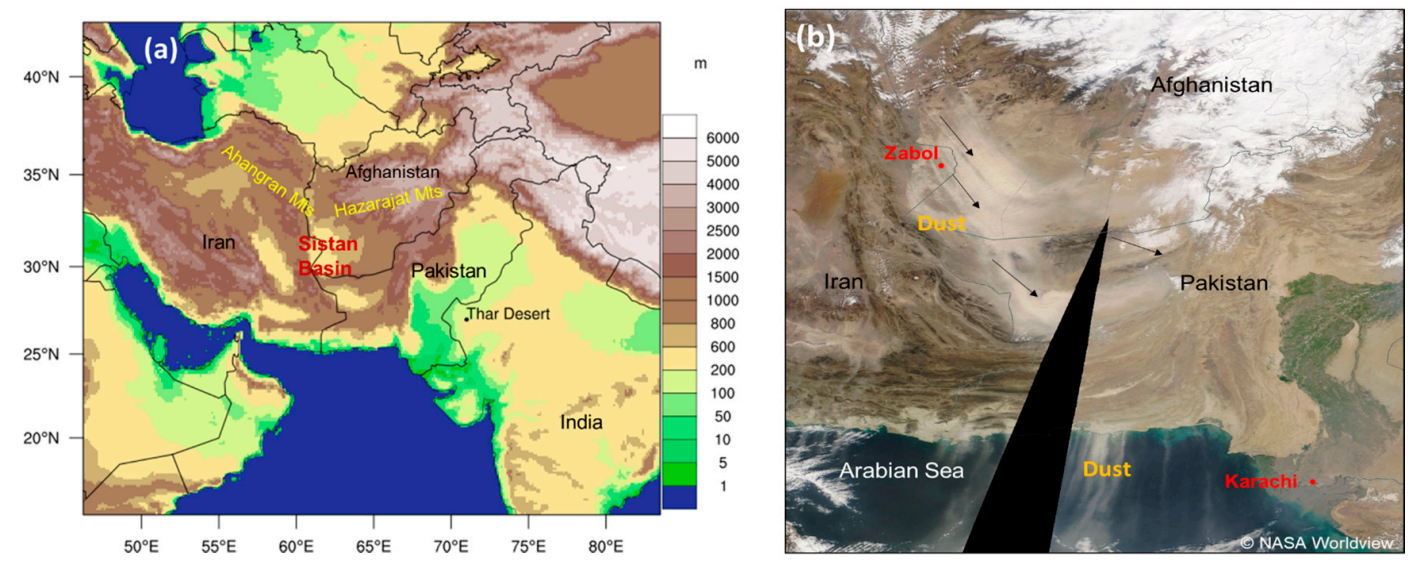

Figure 1. (a) Topography map of the study area and surrounding countries with the terrain elevation map. (b) The dust outbreak over Sistan on 6 February 2019 as seen from Terra Moderate Resolution Imaging Spectroradiometer (MODIS) visible imagery. Image credit: NASA Worldview.

Sistan is impacted by a strong seasonal wind, named Levar or wind of 120 days, during the summer (mid-May-mid-September) period [45]. In summer, but in several cases also during wintertime, the dryness of the Hamoun ephemeral lakes leaves an alluvial saline fine-silt material very prone to wind erosion $[49,51]$. Under favorable conditions of intense near-surface winds, mostly during summer, but occasionally in the other seasons, the Hamoun depression is able to produce massive dust storms, with particulate matter $\left(\mathrm{PM}_{10}\right)$ concentrations and aerosol optical depth (AOD) values above 5-10 mg $\mathrm{m}^{-3}$ and 3.5-5.0, respectively [51,52]. The water coverage in Hamoun Lake depends on both local and regional precipitation as well as snowfall and snowmelt in the Hazarajat Mountains in Afghanistan. Therefore, land cover changes and dryness of the lakes are the most important factors for dust storm occurrence in Sistan, although the relative contribution of each lake is not well established [54]. Recent studies revealed relatively large fractions of $\mathrm{Cl}^{-}$and $\mathrm{Na}^{+}$(7-9\% of the water-soluble inorganic species) in airborne dust implying the presence of saline dust storms with high fractions of evaporated minerals, fine-grain saline particles (e.g., $\mathrm{NaCl}, \mathrm{NaSO}_{4}$ ), and potentially toxic heavy metals [52]. In synopsis, the Sistan Basin constitutes an important region for geological, meteorological, atmospheric, air-quality, and socio-economic research studies. 


\section{Materials and Methods}

\subsection{Zabol Meteorological and Air Quality Data}

Hourly meteorological observations of ambient temperature, mean sea level pressure (MSLP), horizontal visibility, wind speed and direction were obtained at Zabol meteorological station, in order to examine the changes in local/regional meteorology during the passage of the dust storm. Furthermore, hourly $\mathrm{PM}_{10}$ concentrations were measured at Zabol by means of BAM-1020 (Met One Instruments) which uses the beta attenuation mass monitor (http://metone.com/air-quality-particulatemeasurement/regulatory/bam-1020/). The instrumental resolution is $\pm 2 \mu \mathrm{g} \mathrm{m}^{-3}$ and its accuracy $\pm 8 \%$ for $1 \mathrm{~h}$ operation mode [62], as was set up in the current study.

\subsection{Synoptic Meteorology Dataset}

For the analysis of the atmospheric circulation patterns during the dust storm event, meteorological data of wind speed and direction, MSLP, geopotential heights, and temperature at $700 \mathrm{hPa}$ and $500 \mathrm{hPa}$ were obtained from the ERA-Interim reanalysis by the European Centre for Medium-Range Weather Forecasts (ECMWF) at a spatial resolution of $0.5^{\circ} \times 0.5^{\circ}$ and temporal resolution of $6 \mathrm{~h}$ [63]. Comparison of ERA-Interim temperature, pressure, and wind speed against meteorological data from the Zabol station resulted in very low root mean square difference (RMSE) values [43], justifying its accuracy for meteorological applications over southwest Asia.

\subsection{Satellite Observations}

Observations at high spatio-temporal resolution from the Spinning Enhanced Visible and Infrared Imager (SEVIRI) on board the Meteosat Second Generation (MSG-SEVIRI) geostationary satellite were used in this study in order to characterize qualitatively the dust activity over Sistan and transport towards the Arabian Sea. The horizontal distribution of dust is described using the SEVIRI images computed from a combination of three infrared channels, namely channel $10(12 \mu \mathrm{m})$, channel 9 $(10.8 \mu \mathrm{m})$, and channel $7(8.7 \mu \mathrm{m})$. MSG-SEVIRI is located geostationary at $0^{\circ} \mathrm{W}$ over the equator and provides images of southwest Asia on a 15-min temporal resolution. False-color images are created using an algorithm developed by EUMETSAT, which colors red the difference between the 12.0 and $10.8 \mu \mathrm{m}$ channels, green the difference between the 10.8 and $8.7 \mu \mathrm{m}$ channels, and blue the $10.8 \mu \mathrm{m}$ channel [64].

On these false-color composite images clouds appear orange or brown with thick, high-level clouds in red-brown tones and thin high-level clouds appear very dark (nearly black). Dry land looks from pale blue (daytime) to pale green (nighttime). In the desert false-color imagery dust appears pink or magenta with the clearest pink colors arising from high-altitude dust in dry atmospheres. However, the precise color is influenced by numerous environmental properties, such as the surface thermal emissivity and skin temperature, the atmospheric water vapor content, the quantity and height of dust in the atmosphere, and the infrared optical properties of the dust itself. The content of water vapor is found to be the major control on the apparent color of dust, obscuring its presence when the moisture content is high or when the dust is near the surface below the atmospheric water vapor column [64]. Note that the dust effect on brightness temperature differences depends on its altitude suggesting that these composite images may favor the dust which is elevated so that its radiating temperature differs significantly from the ground.

Terra Moderate Resolution Imaging Spectroradiometer (MODIS) L1B MOD021KM retrievals (https://ladsweb.nascom.nasa.gov/data/search.html) of brightness temperature at infrared channels were used for the determination of the emission sources, dust intensity, transport pathways, and affected areas. MODIS Deep Blue level 2 retrievals were not available at the core of the dust storm on 6 February 2019, likely due to exceedance of the MODIS-AOD upper limit of 5 . Therefore, a new index for dust-plume determination, based on brightness temperatures at three thermal infrared MODIS bands: band20 $(3.66-3.84 \mu \mathrm{m})$, band31 $(10.78-11.28 \mu \mathrm{m})$, and band32 $(11.77-12.27 \mu \mathrm{m})$, was used 
following Yue et al. [65]. This index is named the Brightness Temperature Adjusted dust Index (BADI) and was found to provide an accuracy of $>90 \%$, being $7 \%$ and $29 \%$ higher than those derived from the Brightness Temperature Difference $\left(\mathrm{BTD}_{32-31}\right)$ and the normalized difference dust index (NDDI), respectively [65]. BADI is obtained by normalizing Brightness Temperature Index (BDI) between the values -1 and 1 , using the formula:

$$
\mathrm{BADI}=2 / \pi \times \arctan \left(\mathrm{BDI}^{\mathrm{BDI}} \mathrm{B}_{0.95}\right)
$$

where

$$
\mathrm{BDI}=\left(\mathrm{BTD}_{20-31}\right) \alpha \times \mathrm{BTD}_{32-31}
$$

the parameter $\alpha$ was set to 2 and $\mathrm{BDI}_{0.95}$ corresponds to the 95 th percentile of BDI values. The BTD between the two bands $\left(\mathrm{BTD}_{32-31}\right)$ can be used to discriminate the dust presence as positive values [66]. Furthermore, the $\mathrm{BTD}_{20-31}$ may indicate the dust intensity, as band20 exhibits higher forward scattering than band31 [67]. Therefore, the higher the $\mathrm{BTD}_{20-31}$, the thickest the dust plume. BADI values exhibited satisfactory correlation with MODIS Deep Blue AOD for three dust storms in China $\left(R^{2}=0.55-0.79, p<0.01\right)$, implying that it can be used as a measure for the dust thickness [65]. However, a main drawback is that BADI faces difficulties in determining dust over the water surfaces due to much lower brightness temperatures of dust over water than over land [65].

\subsection{AERONET Retrievals}

To examine the effects of the long-range transported Sistan dust plumes, columnar aerosol optical and physical properties (level 1.5; version 3) were obtained from the Aerosol Robotic Network (AERONET) station at Karachi, Pakistan during 4-10 February 2019. Karachi station is located about $1000 \mathrm{~km}$ away from the Sistan Basin in the southeastern direction and is usually affected by dust storms originating from Sistan [55]. In this study, we used AERONET retrievals of the spectral AOD, Ångström exponent ( $\left.\mathrm{AE}_{440-870}\right)$, single scattering albedo (SSA), absorption Ångström exponent (AAE), and columnar volume size distribution.

\subsection{Meso-NH Model Simulations}

The Meso-NH (version 5-3-0) atmospheric model [68,69] was utilized for simulations of the dust characteristics and spatial-temporal evolution of dust over southwest Asia. Meso-NH is a non-hydrostatic mesoscale model coupled with an online dust emission and transport module [70]. The model has been extensively validated against ground-based, airborne, and satellite datasets [41,71-73] and is very capable of simulating the atmospheric dynamics for dust mobilization, dust emission, and transport pathways as previous studies over Sahara have shown $[30,37,74-76]$. In this study, the model was run during four days [from 4 February 2019 at 00:00 UTC (Universal Time Coordinated) to 8 February 2019 at $00: 00$ UTC] over the domain $45^{\circ}-85^{\circ} \mathrm{E}, 15^{\circ}-45^{\circ} \mathrm{N}$, using a horizontal grid of $12 \mathrm{~km}$ and 72 levels in the vertical $(10 \mathrm{~m}-28 \mathrm{~km}), 35$ of which were within the planetary boundary layer (i.e., below $2 \mathrm{~km}$ ). The initial and boundary conditions were taken from the ECMWF. The model run used a rapid radiative transfer model parameterization [77], a mixed-phase bulk microphysical scheme [78], a turbulence parameterization [79], a convective mass-flux scheme [80], and a sub-grid cloud cover and condensate content scheme [81]. The dust scheme includes the Dust Entrainment and Deposition (DEAD) scheme [82] and the ORganic and Inorganic Log-normal Aerosols Model (ORILAM) [83], which parameterizes the transport, dry, and wet deposition of dust.

\section{Results and Discussion}

\subsection{Evolution of the Dust Outbreak on 6-7 February 2019: Satellite Perspective}

The true color imagery from Terra-MODIS shows an intense dust storm over the Sistan Basin and surrounding areas on 6 February 2019, which was rapidly extended south and southeast, affecting 
southern Pakistan and the northern part of the Arabian Sea (Figure 1b). The dust storm originated from the Hamoun ephemeral lakes in the western part of the Sistan Basin. A large part of the dust plume seems to be separated from the major plume, following a southward propagation through a channel between the Sulaiman Mountains and Chagai Hills at the southern edge of the Sistan Basin and affected western Pakistan. In addition, several dust plumes are also seen along the north coast of the Arabian Sea, originating from the sand valleys within the Makran mountainous ranges (Figure 1b).

High temporal (15 $\mathrm{min}$ ) resolution MSG-SEVIRI observations were also used for monitoring the generation and transport of the dust storm (Figure 2). On such imagery, dust is detected with pink/magenta colors (see nomenclature in Figure 2). According to SEVIRI observations, the dust storm originated from Hamoun Lake in the early-morning hours of 6 February and progressively strengthened till about noon, following a U-like pathway over the Sistan Basin. In the afternoon hours of 6 February, the main part of the dust storm was located southeast from Sistan and was significantly weakened. During the evening/night hours of 6 February and on the next day, the dust plume affected the northern part of the Arabian Sea, the lower Indus Basin and travelled as far as the Thar Desert and northwest India, but with significantly lesser intensity.
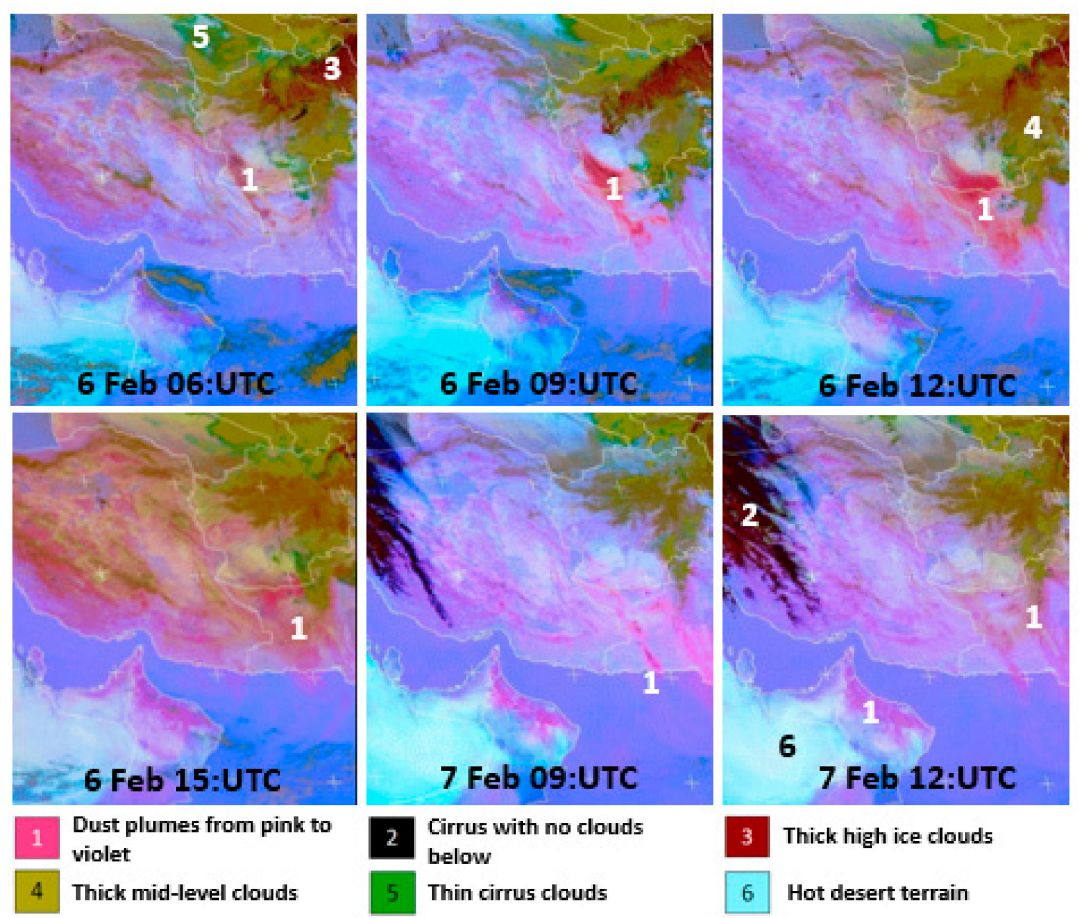

Figure 2. Meteosat (Spinning Enhanced Visible and Infrared Imager) SEVIRI imagery on 6 February 2019 (06:00, 09:00, 12:00, 15:00 UTC) and on 7 February 2019 (09:00, 12:00 UTC). The dust plumes appear in pink and violet in these composite images.

Figure 3 shows the spatial distribution of BADI on 6-7 February 2019 ( 10:30 LST (Local Standard Time); Terra overpass), superimposed by the ERA-Interim winds at $925 \mathrm{hPa}$. BADI justifies that the intense dust storm originated from the northern part of the Hamoun depression, in the flanks of the Margo Desert, and further intensified when passing over the alluvial playas of the Sistan Basin on 6 February (Figure 3a). BADI values were above 0.8 over the Sistan Basin on 6 February and these retrievals show the distribution and propagation of the dust plumes with high accuracy. On 7 February the dust storm over Sistan was significantly weakened, as inferred by the BADI values (Figure $3 b$ ), while the major plume is detected over western Pakistan. The longest dust flanks reached the northeastern Arabian Sea, Indus Basin, and Thar Desert in India favored by the wind regime. Although the synoptic meteorology is seasonally changing over southwest Asia, the dust storms originated from Sistan follow the same pattern and transport pathway independently from the season. 
On this feature, the topography, soil characteristics, development of regional thermal-low systems, and the dominant northerly flow play the major roles $[34,38]$.

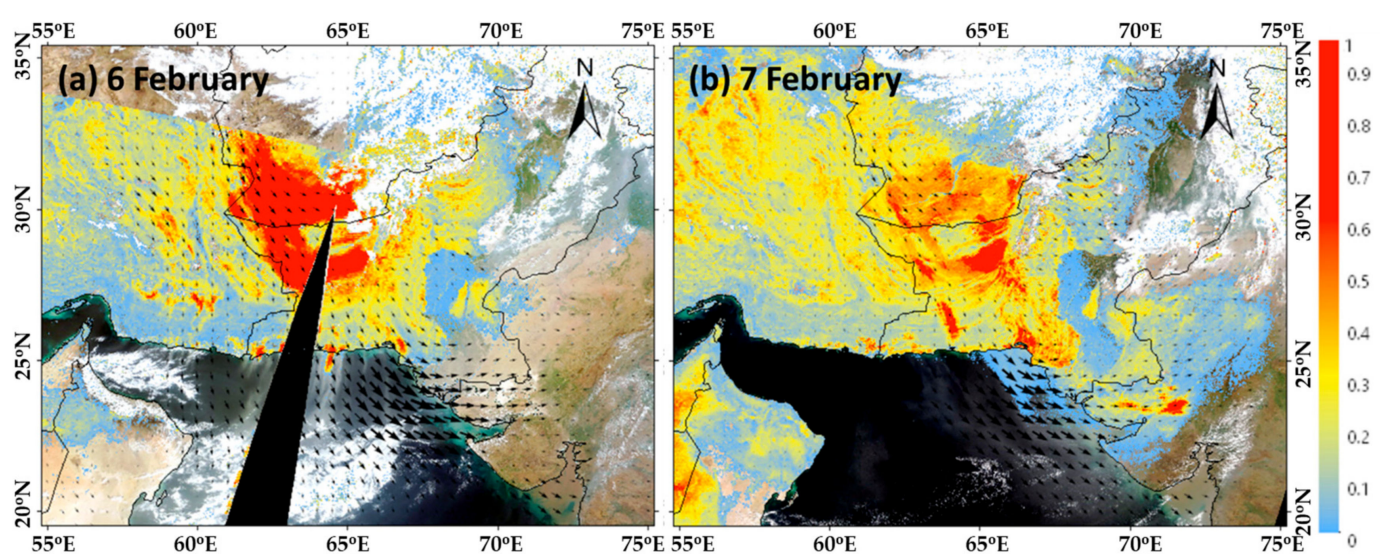

Figure 3. Spatial distribution of the brightness temperature adjusted dust index (BADI) values estimated from Terra-MODIS L1B MOD021KM retrievals superimposed by $925 \mathrm{hPa}$ winds on (a) 6 and (b) 7 February 2019.

\subsection{Synoptic Situation}

During wintertime, the mid-latitude westerlies and the Siberian anticyclone play a major role in weather modification, precipitation, and wind regime over central-west Asia and the Sistan Basin [50,61]. The synoptic situation that dominated during the dust storm event is analyzed in this section via ERA-Interim reanalysis and Meso-NH model simulations. At low levels, the MSLP fields on 5 February 2019 reveal the effect of the Siberian anticyclone over the northern parts of the study domain $(\sim 1040 \mathrm{hPa})$, while lower pressure conditions ( 1012 hPa) dominated over the north Arabian Sea, exhibiting a deepening on 6 and 7 February (Figure 4). A strong pressure gradient existed over the Sistan Basin on 5 and 6 February, setting favorable conditions for strong winds and dust outbreak. Prior to the dust storm (5 February), the MSLP was 12-15 hPa above its climatic (1981-2010) value over northern Iran, the Caspian Sea, and surrounding areas, while this high-pressure anomaly was shifted north-eastward in the next two days. High-pressure conditions also dominated on 5-6 February just north from the Sistan Basin, associated with the intrusion of a cold front from northern latitudes. The winter dust storms over central Asia are strongly related to the western expansion of the Siberian High with cold intrusions toward central and south Asia [84]. During the same time frame, the MSLP was found to be lower than its climatic value $(\sim-6$ to $-9 \mathrm{hPa})$ over Pakistan and northwest India, forming a steep pressure gradient along the Afghanistan-Pakistan border that favored the expansion of the dust plumes towards India on the following days. The dipole of the MSLP anomalies between the Caspian Sea and Hindu Kush, quantified as CasHKI, was found to be at its positive phase, thus favoring the dust activity over Sistan $[34,85]$. ERA-Interim reanalysis (Figure 4) shows a large increase in the wind speed just south of the Hazarajat Mountains in central Afghanistan, while the highest wind speeds were observed over the western Sistan Basin along the corridor between the Hazarajat Mountains and Bagheran and Ahangran rocky hills due to the channeling effect by the mountains, as previously shown by several modeling and observational studies $[38,42,86,87]$. These winds are the result of the strong MSLP gradients over this region (Figure 4) and the trigger for the intense dust storm. 


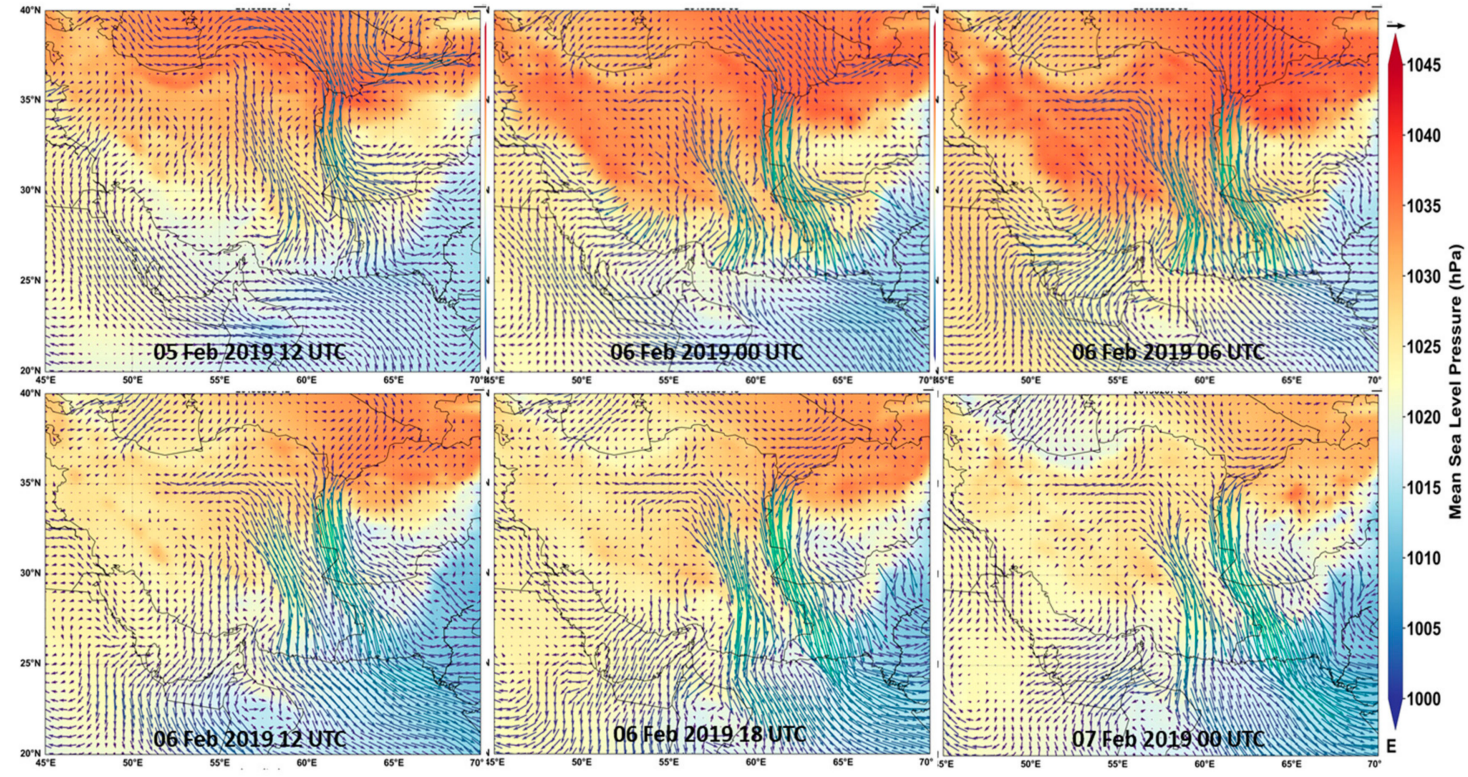

Figure 4. Mean sea level pressure (MSLP) variations superimposed with $850 \mathrm{hPa}$ winds over southwest Asia on certain hours during 5-7 February 2019 according to ERA-Interim reanalysis.

At high levels, the situation was depicted from synoptic maps of the geopotential heights at 700 and $500 \mathrm{hPa}$ along with temperature (ERA-Interim; Figure 5) and Meso-NH simulations of geopotential heights and wind at $500 \mathrm{hPa}$ (Figure 6). The intrusion of an upper-level trough from high latitudes occurred over the western flanks of the Sistan Basin on 5 February and the trough moved southeastward toward Pakistan during the following days. On 6 February the trough had evolved to a cut-off low, visible initially in the upper troposphere, and then it was transferred gradually to lower altitudes as it moved southeastward. On the day of the dust outbreak, the occurrence of the cut-off low was detected over Afghanistan, where it initiated unstable weather conditions after interaction with the orography there. Extensive cloudiness over the Hazarajat and Hindu Kush mountains in Afghanistan (white colors in Figure $1 \mathrm{~b}$ and ochre and brown colors in Figure 2) reflects the development of convection over the mountains by orographic forcing and under the influence of the cut-off low. The core of the cut-off low was determined at $\sim 3000$ and 5500 gpm at $700 \mathrm{hPa}$ and $500 \mathrm{hPa}$, respectively, and was associated with very cold intrusion with temperatures around $8-10{ }^{\circ} \mathrm{C}$ below the surroundings and about $14{ }^{\circ} \mathrm{C}$ lower that the climatic values (Figure 5). The ERA-Interim reanalysis clearly shows this cold intrusion associated with the cold front over the Sistan Basin and surroundings on 5-6 February, while on 7 February the cold intrusion was weakened over Sistan and mainly detected over Pakistan, following the eastward movement of the main stream. Atmospheric dynamics during this event were also examined based on three-hour runs of the Meso-NH model with high (12 km) spatial resolution during 5-7 February 2019 (Figure 6). The geopotential heights and vector wind at $500 \mathrm{hPa}$ verify the development of the deep trough on 5 February, which formed a closed upper-level "cut-off low" over Afghanistan and Pakistan on 6-7 February. This cut-off low moved southward and then eastward, then progressively weakened and dissipated two days later. 


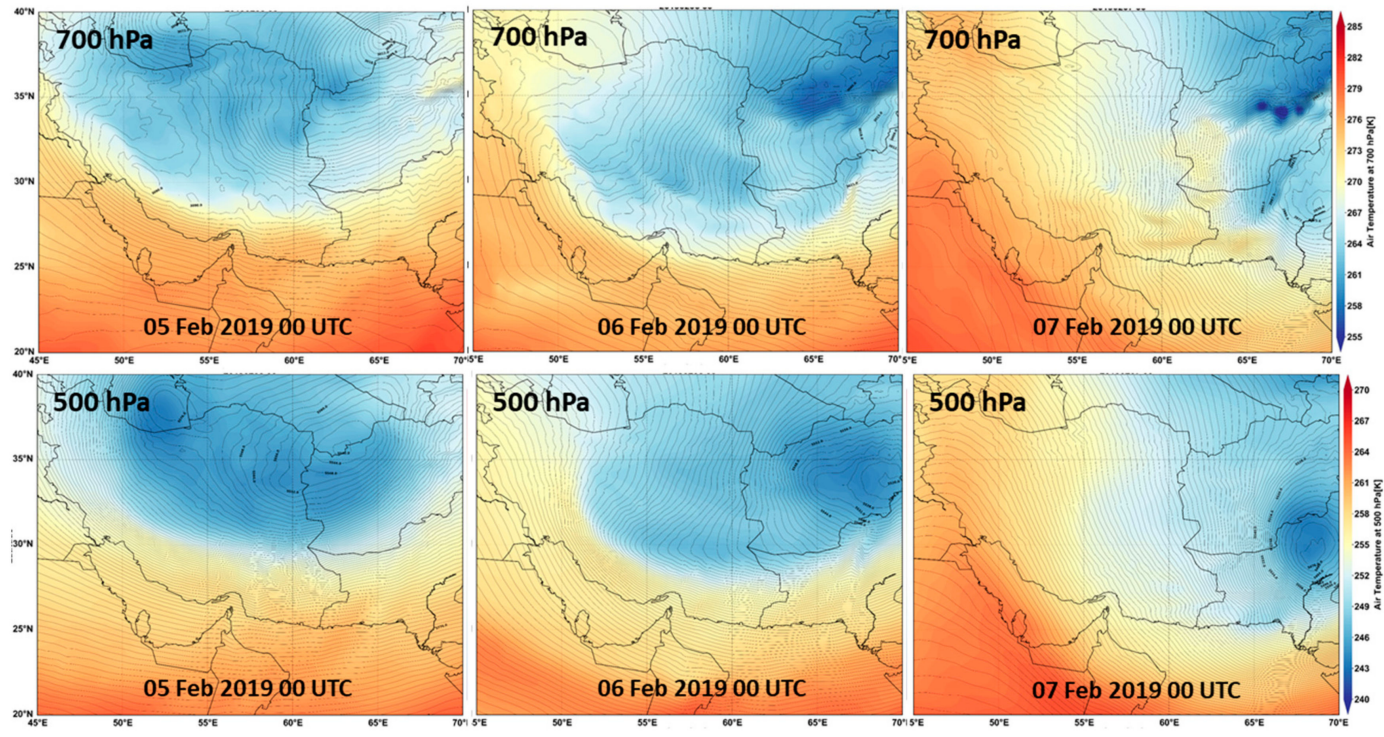

Figure 5. Air temperature at $700 \mathrm{hPa}$ (upper row) and $500 \mathrm{hPa}$ (bottom row) over southwest Asia on 5-7 February 2019 according to ERA-Interim reanalysis. The contours correspond to geopotential height variations at the same levels.

High positive values of potential vorticity (4-8 PVU) at $300 \mathrm{hPa}$ were seen around $30^{\circ}-35^{\circ} \mathrm{N}$ associated with the intrusion of the upper-level trough. The high PVU values follow a southeastward propagation, reaching over the north Arabian Sea $\left(22^{\circ} \mathrm{N}\right)$ on 7 February (Figure 6$)$. The equivalent potential temperature (Theta) simulated by the model shows two distinct air masses: one cold and dry to the north of $25^{\circ} \mathrm{N}$ and one moist and warm to the south of $25^{\circ} \mathrm{N}$. The Theta maps clearly show the intrusion of the cold and dry air from central Asia toward Sistan, along the corridor between the mountains, while the cold air masses push the warm air to southern latitudes over the north Arabian Sea and northwest India.

Cut-off cold lows in the middle and upper troposphere are usually developed over the subtropics and mid-latitudes associated with penetrating deep troughs from high latitudes $[30,87,88]$. They usually begin as a trough, as was shown on 5 February, and progressively become a closed circulation with a cold core, which may be stationary for days and be extended down to the surface forming a baroclinic system with unstable weather conditions $[30,89,90]$. The cut-off low in our case was transferred to low levels when it reached central Afghanistan on 6 February and it caused the development of deep convection facilitated by orographic blocking. The development of deep convection over Afghanistan was accompanied by the generation of cold downdrafts enhanced by evaporational cooling over the desert areas [30,39]. This generated a mesoscale density current-like flow in the dry desert detected at the surface as a cold front and caused additional dust emissions [91].

The transfer to the surface of the cut-off low also caused intensification of low-level winds around the low. A surge of northwesterlies over the Sistan Basin, located to the west of the pressure-low was observed, further enhanced by the wind channeling effect. Model simulations showed violent winds $\left(>20 \mathrm{~ms}^{-1}\right.$ ) at $850 \mathrm{hPa}$, initially over the southern Karakum Desert (5 February) and progressively over Sistan and western Pakistan (Figure 6). Abbasi et al. [59] agreed that the highest winds throughout the Sistan Basin were determined over the Hamoun ephemeral lakes and gradually decreased over the Registan Desert in the east, similarly to the current case. Intense winds $\left(>10 \mathrm{~ms}^{-1}\right)$ were also seen over parts of the north Arabian Sea and northwest India, facilitating the dust transport over these areas. The highest wind speeds are simulated over the Hamoun depression, following the north-to-south corridor between the mountainous ranges. The three-hour model simulations revealed an increase in wind speed during the early morning hours, resulting from the downward transfer of momentum from the nocturnal low-level jet due to turbulent mixing after solar heating started $[37,38,87]$. 

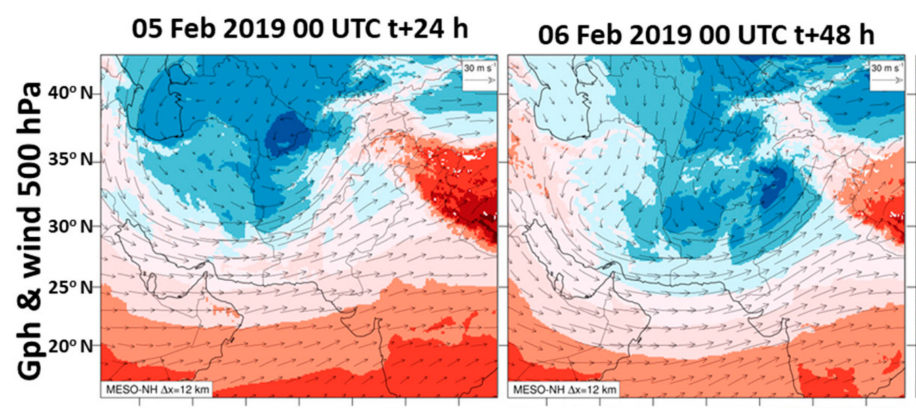

07 Feb 201900 UTC $t+72 h$
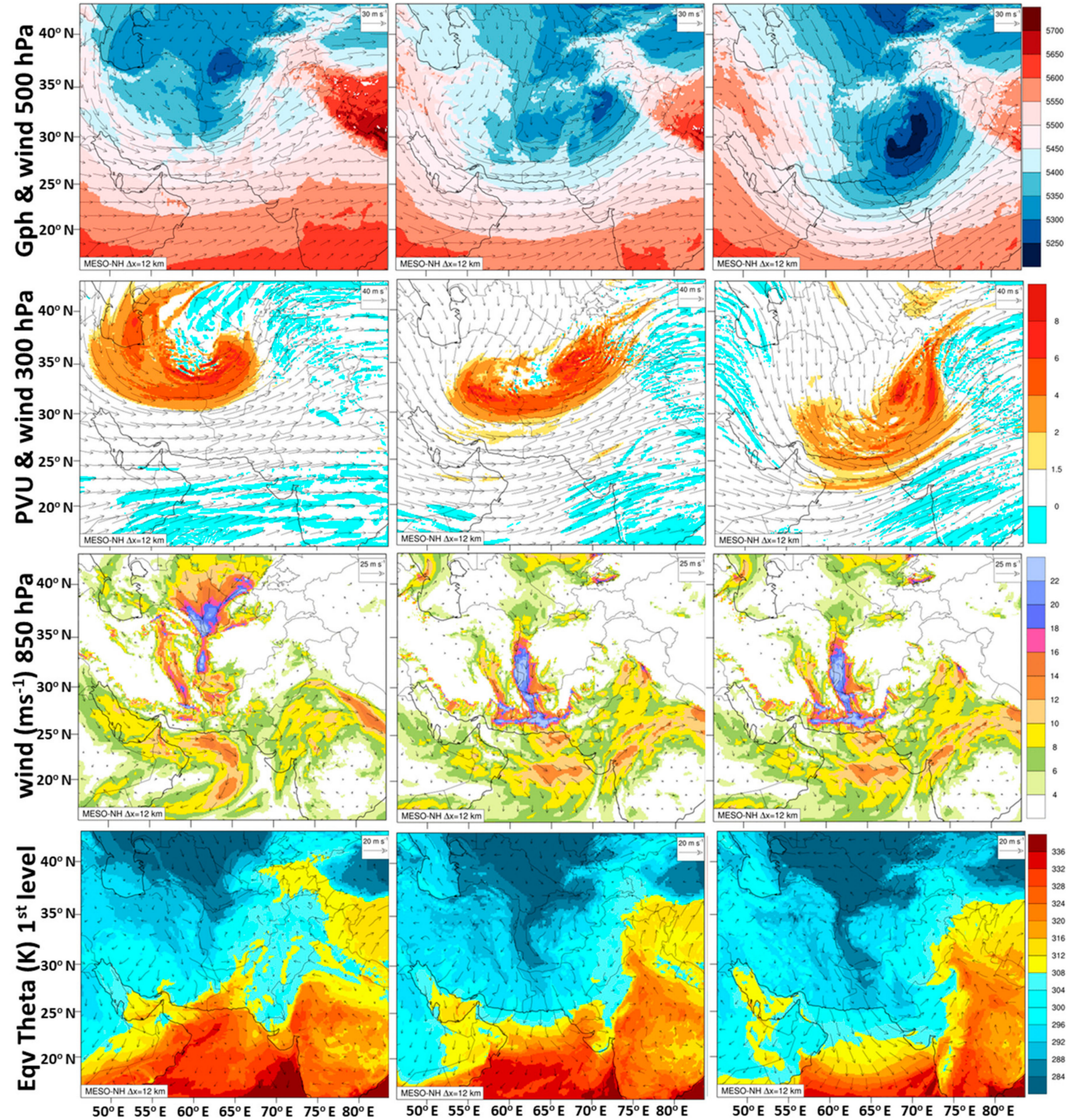

Figure 6. Meso-NH simulations of the geopotential height and vector wind at $500 \mathrm{hPa}$ (first row), potential vorticity and vector wind at $300 \mathrm{hPa}$ (second row), wind speed at $850 \mathrm{hPa}$ (third row), and equivalent Theta (forth row) over southwest Asia during 5-7 February 2019.

\subsection{Local Impact and Air Quality}

During the passage of the cold front and the associated dust storm remarkable changes in local meteorology and $\mathrm{PM}_{10}$ concentrations were recorded at Zabol (Figure 7). The maximum temperatures of $\sim 18-22{ }^{\circ} \mathrm{C}$ on 4 and $8-10$ February dropped to $\sim 10-11^{\circ} \mathrm{C}$ on $5-6$ February due to the passage of the cold front (Figure 7a); while a radiative cooling of dust cannot be ignored, its contribution is difficult to be quantified. In comparison, the dustiest conditions during wintertime at Zabol meteorological station detected for long-term analysis ( 10 years) were associated with an average temperature decrease of $2-4{ }^{\circ} \mathrm{C}$. Similarly, Maghrabi et al. [92] and Alharbi et al. [93] reported a remarkable $\left(\sim 6^{\circ} \mathrm{C}\right)$ temperature decrease over Riyadh, Saudi Arabia during a severe dust storm on 10-11 March 2009 due to dust radiative cooling and the passage of a north frontal system. Moreover, Jish Prakash et al. [22] estimated a large reduction of -6.7 degrees in surface temperature over the Middle East due to dust radiative cooling during the severe episode of 18-22 March 2012. 
(a)

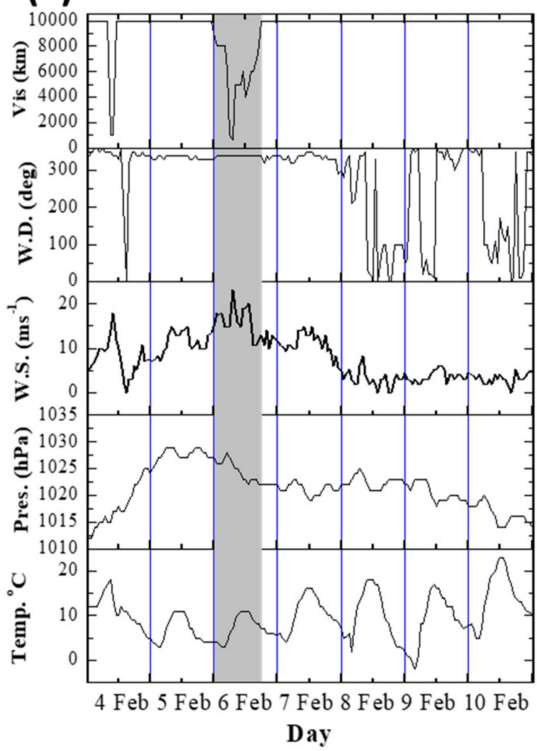

(b)



Figure 7. Temporal variation of (a) the hourly meteorological parameters and (b) hourly $\mathrm{PM}_{10}$ concentrations in Zabol during 4-10 February 2019. The dust storm hours at the station are highlighted in grey. The red squares with the vertical bars correspond to daily mean $+/-1$ standard deviation.

During the passage of the cold front, just prior to the dust storm, the pressure increased by approximately $14 \mathrm{hPa}$ (from $1014 \mathrm{hPa}$ to $1028 \mathrm{hPa}$ ), and then started to decrease gradually exhibiting small fluctuations (Figure 7a). A remarkable increase in the wind speed from $\sim 10 \mathrm{~ms}^{-1}$ to $\sim 18-20 \mathrm{~ms}^{-1}$ was observed just before and during the peak of the dust storm in the morning hours of 6 February 2016 (grey area, Figure 7a), while after the passage of the dust storm, the wind speed returned to its pre-dust levels (around $5 \mathrm{~ms}^{-1}$ ). The wind direction was northerly throughout the dust episode and in the next days, with some contributions from northeastern directions after 8 February. As expected, the severe dust storm caused a dramatic decrease in horizontal visibility from $10 \mathrm{~km}$ to about 100-200 m in the morning hours on 6 February. The reduced visibility lasted for about 18 hours, indicating a fast-propagating dust storm triggered by severe winds.

The hourly evolution of the $\mathrm{PM}_{10}$ concentrations in Zabol (Figure $7 \mathrm{~b}$ ) shows a remarkable increase to high peaks in the morning hours of 6 February (06:00 LST), directly impacted by the dust emissions from the Hamoun drylands which started at that time. The hourly $\mathrm{PM}_{10}$ concentrations reached $\sim 1800 \mathrm{\mu g} \mathrm{m}^{-3}$ at 08:00 LST, while they had decreased to below $500 \mathrm{\mu g} \mathrm{m}^{-3}$ until the early afternoon and by less than $100 \mu \mathrm{g} \mathrm{m}^{-3}$ during the evening hours. The daily mean $\mathrm{PM}_{10}$ levels reached up to $400 \mu \mathrm{g}$ $\mathrm{m}^{-3}$ on 6 February, while on 7 February they decreased to $76 \mu \mathrm{g} \mathrm{m}^{-3}$. Previous studies reported daily mean $\mathrm{PM}_{10}$ levels of 2000-3000 $\mu \mathrm{g} \mathrm{m}^{-3}$ during intense summer dust storms in Zabol [44], while in certain cases $\mathrm{PM}_{10}$ levels can reach up to $10,000 \mathrm{\mu g} \mathrm{m}^{-3}$ [51,52]. This implies that the current episode is of a rather moderate intensity for Sistan, but it can be considered as specifically intense for the winter period, which does not support the occurrence of this severe phenomenon. The dust erosion exhibited a great consistency with the sudden increase in wind speed in the morning hours of 6 February (Figure 7a), while another sudden increase in wind speed on 4 February was also associated with intense local dust emissions $\left(\sim 1600 \mu \mathrm{g} \mathrm{m}^{-3}\right)$ of limited duration $(\sim 1 \mathrm{~h})$. Therefore, precise forecast and early warning for intense dust outbreaks over Sistan are of vital importance for mitigation of their impacts on transportation, aviation, ecosystems, and human health [53,94].

\subsection{Characteristics of the Dust Storm}

This section examines the temporal, spatial, and vertical evolution of the dust loading and concentration over Sistan and surrounding areas alongside the wind regime based on Meso-NH 
simulations. The near-surface winds and the vertical stratification are key parameters for genesis, development, and movement of dust [74,95]. Local and regional topography play a major role in wind regime, and more specifically in the modulation of winds and associated dust emissions in Sistan [38,42]. The highest dust AODs are located over the Hamoun depression (Figure 8), also associated with the highest winds (Figures 4 and 6). The strong northerlies associated with the cold front were able to erode large amounts of alluvial silt and sand from the Hamoun dry beds and surrounding arid areas in the morning hours of 6 February, increasing the dust AOD to levels above 3.0 (Figure 8). Meso-NH simulations also revealed high dust AODs over the northern parts of the Arabian Sea, even from the morning hours of 6 February, which progressively increased, and then expanded to southern latitudes $\left(\sim 20^{\circ} \mathrm{N}\right)$ on 7 February with dust AODs of $\sim 2.0$. Dust AODs of 0.8-2.0 were also detected over the Thar desert on 7 February due to long-range transport of dust from Sistan and not to a new dust outbreak over the Thar. Previous studies [34,57] also revealed a small influence of Sistan dust storms in northwest India. According to Meso-NH simulations, the dust-mass column density reached $15 \mathrm{~g}$ per $\mathrm{m}^{2}$ on 6 February over Sistan, during the peak of the dust storm intensity (Figure S3). Dust loads varying from about $5-10 \mathrm{~g} \mathrm{~m}^{-2}$ were observed over areas in the northern part of the Arabian Sea, western Pakistan, and the Thar Desert on 7 February 2019.
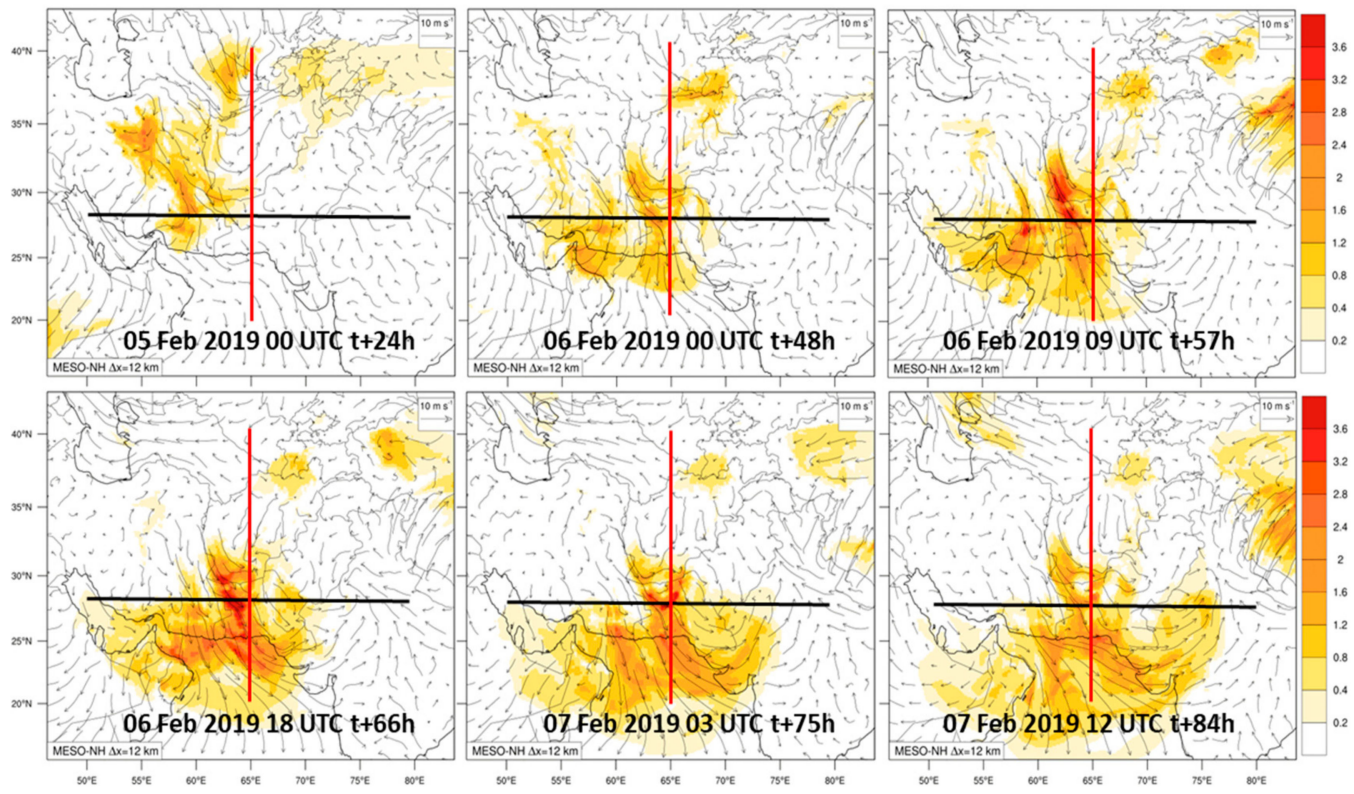

Figure 8. Spatial distribution of the dust AOD simulated by the Meso-NH model for certain hours during 5-7 February 2019 over southwest Asia.

Figure 9 shows the longitude-altitude cross section of the dust concentration along $28^{\circ} \mathrm{N}$ (black line in Figure 8). The highest dust concentrations approaching $5000 \mu \mathrm{g} \mathrm{m}^{-3}$, were detected in the rough topography over western Pakistan. The dust plumes reached $1.5-2.0 \mathrm{~km}$ above ground level over the source area but they expanded in the vertical during the eastward transport and reached $3 \mathrm{~km}$ over the Thar Desert on 7 February. The dust concentration above the Thar Desert was significantly weakened compared to that over western Pakistan. However, model simulations reveal significant dust concentrations at the surface $\left(\sim 500 \mu \mathrm{g} \mathrm{m}^{-3}\right)$ over distances more than $1000 \mathrm{~km}$ away from the source area. The wind regime shows a westerly direction, while weak zonal winds dominated over the dust source regions, and in general, below $2 \mathrm{~km}$ on 6 February, which increased on 7 February, facilitating the eastwards transport of dust. Topography significantly affects the near-surface wind speed, causing upward and downward movements of air along the mountainous terrain that affect the transport and deposition of dust [26,38]. 

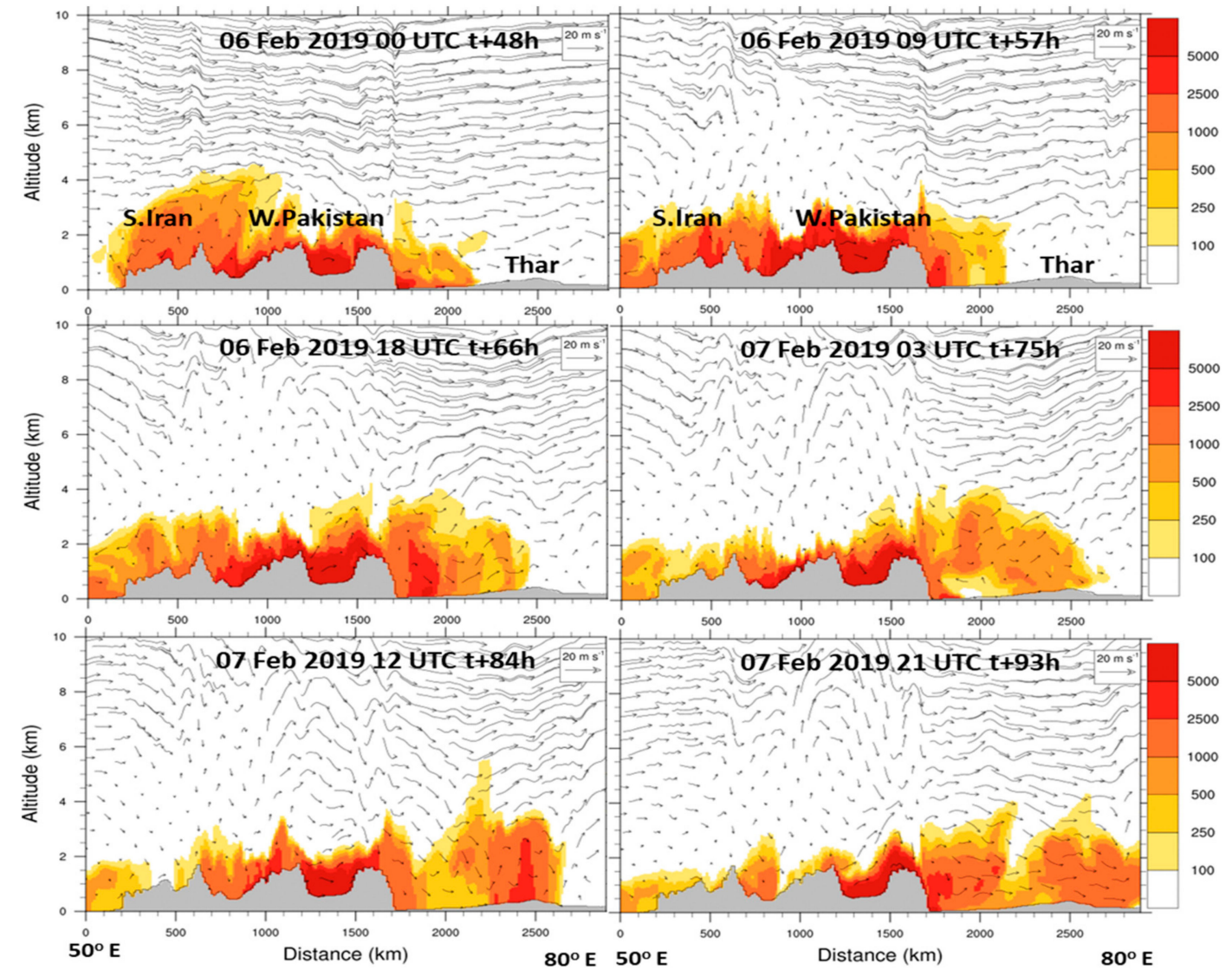

Figure 9. Vertical cross sections of dust concentration (in $\mu \mathrm{g} \mathrm{m}^{-3}$ ) from $50^{\circ} \mathrm{E}$ to $80^{\circ} \mathrm{E}$ along $28^{\circ} \mathrm{N}$ (black line in Figure 8) for certain hours during 5-7 February 2019 (LST = UTC + 5.30). The winds along the cross sections are superimposed in vectors. The distance is in $\mathrm{km}$ starting from $50^{\circ} \mathrm{E}$.

The respective latitude-altitude cross sections of the dust concentration along $65^{\circ} \mathrm{E}$ (east Sistan Basin; red line in Figure 8) during 5-7 February 2019 are presented in Figure 10. The model simulations show that the majority of the uplifted dust in the early morning of 6 February remained at lower levels $(<2.0 \mathrm{~km})$ over the Sistan Basin. The southward-moving dust plume was able to overcome the coastal Makran ranges $(\sim 1.5 \mathrm{~km})$ and be transported over the marine environment, while the coastal region seemed to contribute with new dust emissions, as also seen from satellite observations (Figure 1b). During daytime on 6 February, convective mixing due to solar heating at the surface, mixed the dust throughout the boundary layer reaching $3-4 \mathrm{~km}$ in altitude, which made it available for long range transport by the northerlies and westerlies.

The intensification of the low-level winds due to the passage of the cold front and the associated cut-off low can be seen on the vertical cross section at the Sistan latitude. On 6 February an upper-level $(\sim 8-10 \mathrm{~km})$ intense subtropical jet from a southern direction was developed over the southern latitudes, which shifted to northerlies with a similar intensity on 7 February. At higher atmospheric levels (above $\sim 4 \mathrm{~km}$ ), strong winds with katabatic tendency were observed at latitudes north of Sistan. These winds are associated with the southward movement of the trough and the cold front near the surface. The intense upper-troposphere winds and the increased baroclinicity caused violent wind speeds at the lower troposphere and the surface $[95,96]$. The Sistan Basin is highly affected by strong katabatic winds from the southern lee slopes of the Hazarajat Mountains to the plains (Figure 10). The cold katabatic wind currents accelerated toward the plains and formed high turbulent winds, which caused uplift of thick dust plumes [71,97]. 


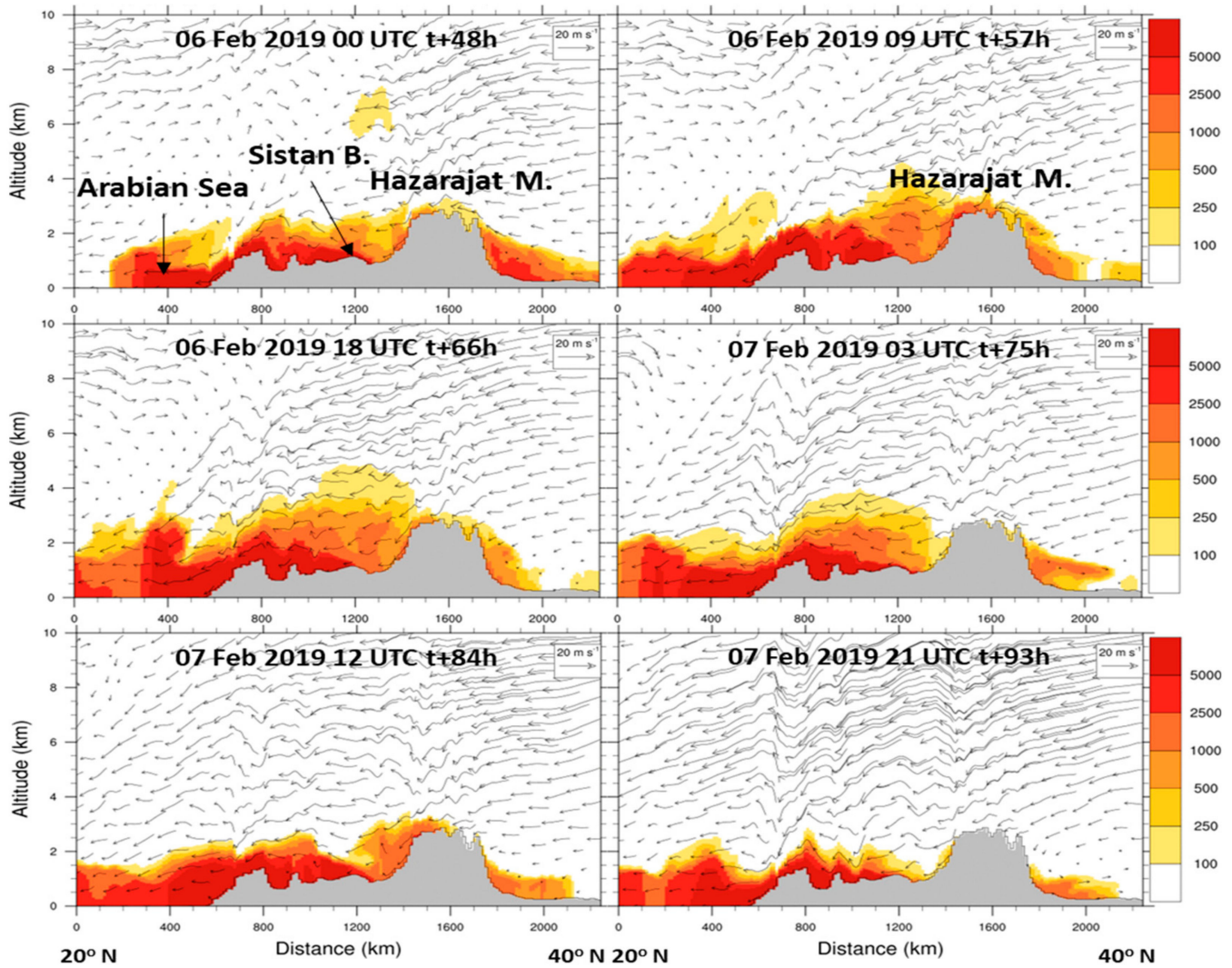

Figure 10. Vertical cross sections of dust concentration (in $\mu \mathrm{g} \mathrm{m}^{-3}$ ) from $20^{\circ} \mathrm{N}$ to $40^{\circ} \mathrm{N}$ along $65^{\circ} \mathrm{E}$ (red line in Figure 8) for certain hours during 5-7 February 2019 (LST = UTC + 5.30). The winds along the cross sections are superimposed in vectors. The distance in $\mathrm{km}$ starts from $20^{\circ} \mathrm{N}$.

\subsection{Long-Range Transport of Dust and Impact on Aerosol Properties}

Figure 11a shows the time series of the hourly $\mathrm{AOD}_{500}$ values in Karachi as a function of $\mathrm{AE}_{440-870}$ during 4-10 February 2019. The $\mathrm{AOD}_{500}$ ranged from 0.18 to 1.37 , with $\mathrm{AE}$ range from around 0 to $\sim 1.5$, indicating a remarkable variability in the aerosol loading and dominant types. Alam et al. [55] studied a dust event over Karachi on 21 July 2007, which presented similar characteristics to the current case, since a thick dust plume that originated from the Sistan Basin two days earlier affected the whole region including the north Arabian Sea. The Sistan dust storm increased the $\mathrm{AOD}_{500}$ at Karachi to 1.36 with AE values below 0.3, very similar to the current case. Due to the large distance from the dust source, the AOD values in Karachi were much lower than those near the source region. In addition, the dust storm slightly increased the SSA values ( 0.97) and caused a remarkable increase in $\mathrm{AAE}_{440-870}$ to levels above 2.5, due to the significant absorption of dust at short wavelengths (Figure 11b). The dust impact on atmospheric aerosol composition and optical properties over Karachi occurred about $24 \mathrm{~h}$ after the dust outbreak in the Sistan Basin, revealing an average movement of the dust plume of about $40 \mathrm{~km} / \mathrm{hr}$. 

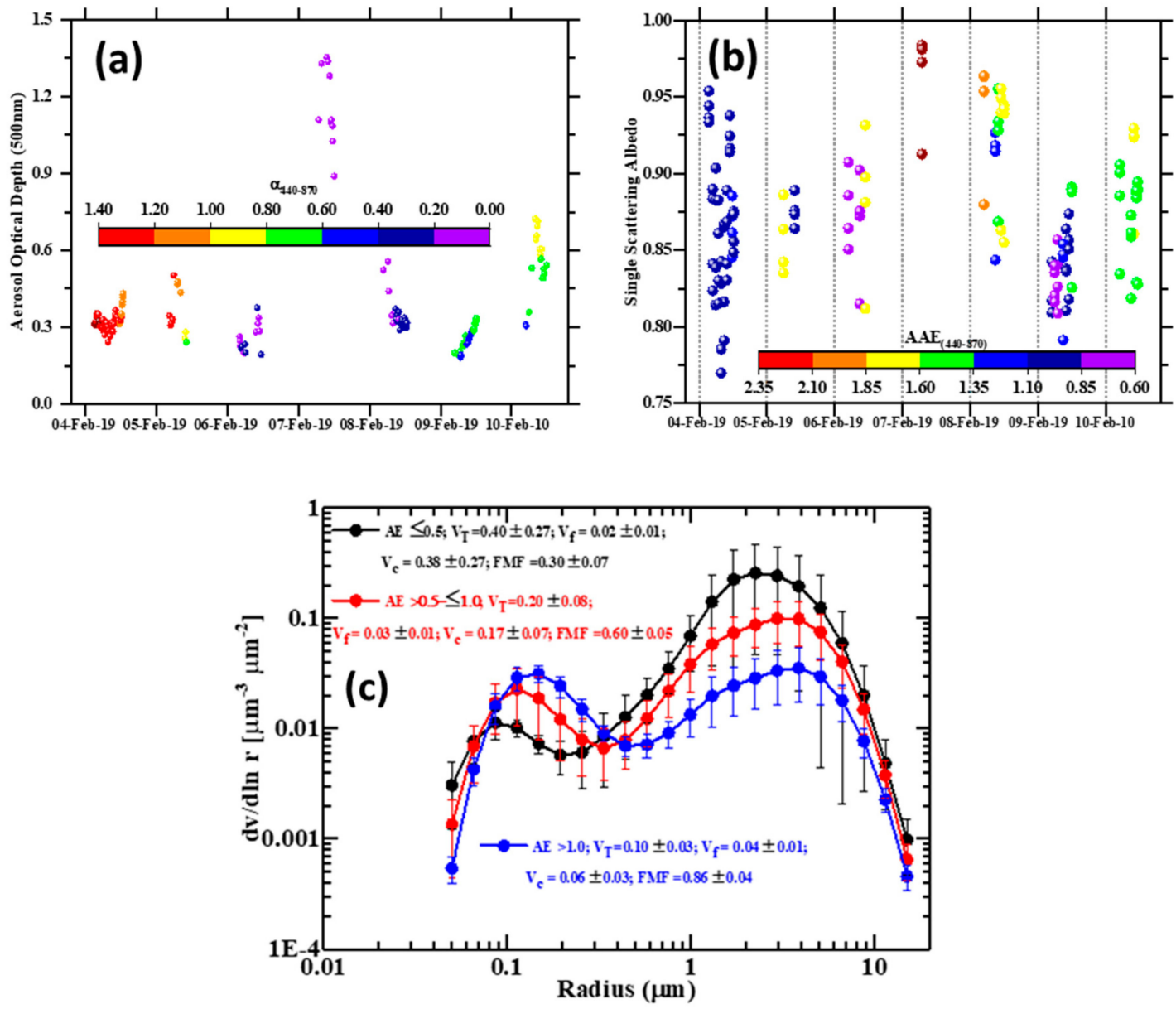

Figure 11. (a) Time series of the $\mathrm{AOD}_{500}$ values as a function of $\mathrm{AE}_{440-870}$ (colored scale); (b) single scattering albedo (SSA) as a function of $\mathrm{AAE}_{440-870}$; and (c) volume size distributions grouped for three $\mathrm{AE}_{440-870}$ clusters $(\mathrm{AE}<0.5,0.5<\mathrm{AE}<1.0, \mathrm{AE}>1.0$ ) at Karachi AERONET station during 4-10 February 2019.

The distribution of the volume aerosol size (dV/dlnr) at Karachi during 4-10 February 2019 was classified in three groups of AE (Figure 11c), revealing a large dominance of coarse-mode particles on 7 February 2019 (AE < 0.5). The $\mathrm{dV} / \mathrm{dln} r$ curves present remarkable changes depending on the spectral distribution of the AOD, while the $V_{t}, V_{f}, V_{c}$, and fine-mode fraction (FMF) values are also mentioned for each AE class. The arrival of the dust storm over Karachi caused a significant reduction of FMF $(0.30 \pm 0.07)$ and increase of $\mathrm{V}_{\mathrm{c}}=0.38$ compared to days dominated by urban pollution (AE $\left.>1.0\right)$. The $\mathrm{dV} / \mathrm{dlnr}$ curve presents a shift towards lower fine and coarse mode radii compared to the urban pollution cases, which may represent coagulation of anthropogenic aerosols to larger sizes (Figure 11c). The coarse mode maximizes at $2.24 \mu \mathrm{m}$.

Both satellite observations and model simulations reveal an important dust impact over the north part of the Arabian Sea. Excessive deposition of dust minerals like iron and phosphorus over the marine environment may affect the ocean bio-geochemistry, chlorophyll blooming, phytoplankton production, and may cool the ocean surface $[98,99]$, while other studies found that dust presence over the Arabian Sea may affect cloud microphysics, monsoon circulation, and rainfall rates $[13,100,101]$. Previous analysis showed a correlation of $\mathrm{R}^{2}=0.22$ between the frequency of the Sistan dust storms and the AOD values over the northeastern part of the Arabian Sea during summer [56,57], indicating that Sistan is one of the major contributors to the aerosol loading over the marine environment and may aid in nutrient, bacteria, and organic redistribution over southwest Asia. 


\section{Conclusions}

This study examined the synoptic and dynamic meteorological processes that facilitated an intense dust storm in the Sistan Basin during winter (6-7 February 2019), which affected the northeastern part of the Arabian Sea and megacity Karachi. Satellite (MODIS, SEVIRI) observations, along with reanalysis (ERA-Interim) data, local meteorological observations, AERONET (Karachi station) measurements, and Meso-NH model simulations were synergized. SEVIRI images at high temporal resolution of $15 \mathrm{~min}$ helped to identify the time and source of origin of the dust storm that was determined at around 06:00 LST on 6 February over the northern part of the Hamoun dried lakes in the western Sistan Basin.

The episode of strong winds $\left(\sim 20 \mathrm{~ms}^{-1}\right)$ over the Sistan Basin, at the origin of the dust outbreak, was caused by the intrusion of a cold front and an upper PV-trough from high latitudes on 5 February. The trough evolved into an upper-level cut-off low on 6 February and was transferred to low levels over Afghanistan. The southward propagation of the cold front caused massive soil erosion from the Hamoun dry-bed lakes and activated other dust sources in southern Iran and western Pakistan that affected the northern part of the Arabian Sea. The cold front was typified at the surface by a sharp decrease $\left(-10^{\circ} \mathrm{C}\right)$ in air temperature, while in the mid-troposphere the temperature was about $12-14{ }^{\circ} \mathrm{C}$ below the climatic value. The pressure low over Afghanistan caused the intensification of winds around it including low-level jet over the Sistan Basin, which exhibited a surge on the day of the dust storm due to channeling effect by the mountainous ranges. Additional dust emission was caused by density currents emanating from the developing deep convection over Afghanistan under the influence of the cut-off low. Evaporational cooling and wind acceleration downslope from the mountains resulted in even stronger turbulent surface winds causing strong dust uplift and rapid transport toward the Arabian Sea and northwest India.

Meso-NH simulations revealed very high dust loads and concentrations over the study region and a vertical distribution of dust up to $3 \mathrm{~km}$. Long-range transport of dust plumes increased significantly the AOD values in Karachi one day after the initial emissions and modified the aerosol optical and physical properties. Overall, the dust activity in the Sistan Basin is a function of several interrelated parameters, such as topography, soil characteristics, rainfall, water and vegetation cover, synoptic meteorology, local winds, and convective activity. However, the large-scale dynamics were of crucial importance in the generation and the sustenance of the wintertime dust storm investigated here. A steep northwest-southeast pressure gradient across the Sistan Basin triggered the intense northerly flow along the east Iran borders, which was further intensified by channeling effects over the Sistan Basin.

The Sistan Basin has attracted high scientific interest during the last decade from meteorological, climatological, geological, and air-quality perspectives. Analysis of the meteorological patterns and atmospheric dynamics that facilitate dust emissions over this major dust source, for the different seasons of the year, may enable an early warning system to prevent the local population from being exposed to the adverse dust effects and to protect their lives and belongings.

Supplementary Materials: The following are available online at http://www.mdpi.com/2076-3263/9/10/453/s1, Figure S1: Supplementary Figures.

Author Contributions: D.G.K. organized the research and wrote the manuscript. D.F. was involved in modeling and meteorological writing/discussions. J.-P.C. provided the model simulations. A.R. analyzed the MODIS data and estimated BADI. U.C.D. contributed to the analysis. All authors provided comments and suggestions in the manuscript.

Funding: This research was supported by the project "PANhellenic infrastructure for Atmospheric Composition and climatE change" (MIS 5021516), under the Action "Reinforcement of the Research and Innovation Infrastructure", funded by the Operational Programme "Competitiveness, Entrepreneurship and Innovation" (NSRF 2014-2020) and co-financed by Greece and the European Union (European Regional Development Fund).

Acknowledgments: The MODIS retrievals via the Giovanni visualization system (https://giovanni.sci.gsfc.nasa. gov/giovanni/) are highly acknowledged as well as the Meteosat-SEVIRI, MODIS and Sentinel imagery that were used in this work. ERA-Interim reanalysis data are also appreciated. The PIs of the Karachi AERONET station (Brent Holben and Badar Ghauri) are greatly acknowledged for their efforts in station maintenance and data release. 
Conflicts of Interest: The authors declare no conflicts of interest.

\section{References}

1. Goudie, A.S.; Middleton, N.J. Desert Dust in the Global System; Springer Science \& Business Media: Berlin, Germany, 2006.

2. Shao, Y.; Wyrwoll, K.H.; Chappell, A.; Huang, J.; Lin, Z.; McTainsh, G.H.; Mikami, M.; Tanaka, T.Y.; Wang, X.; Yoon, S. Dust cycle: An emerging core theme in Earth system science. Aeolian Res. 2011, 2, 181-204. [CrossRef]

3. Middleton, N.J. Desert dust hazards: A global review. Aeolian Res. 2017, 24, 53-63. [CrossRef]

4. Schepanski, K. Transport of Mineral Dust and Its Impact on Climate. Geosciences 2018, 8, 151. [CrossRef]

5. Formenti, P.; Caquineau, S.; Desboeufs, K.; Klaver, A.; Chevaillier, S.; Journet, E.; Rajot, J.L. Mapping the physico-chemical properties of mineral dust in western Africa: Mineralogical composition. Atmos. Chem. Phys. 2014, 14, 10663-10686. [CrossRef]

6. Lovett, C.; Sowlat, M.H.; Saliba, N.A.; Shihadeh, A.L.; Sioutas, C. Oxidative potential of ambient particulate matter in Beirut during Saharan and Arabian dust events. Atmos. Environ. 2018, 188, 34-42. [CrossRef]

7. Oduber, F.; Calvo, A.I.; Blanco-Alegre, C.; Castro, A.; Nunes, T.; Alves, C.; Sorribas, M.; Fernández-González, D.; Vega-Maray, A.M.; Valencia-Barrera, R.M.; et al. Unusual winter Saharan dust intrusions at Northwest Spain: Air quality, radiative and health impacts. Sci. Total Environ. 2019, 669, 213-228. [CrossRef]

8. Shao, Y.; Klose, M.; Wyrwoll, K.H. Recent global dust trend and connections to climate forcing. J. Geophys. Res. 2013, 118, 11-107. [CrossRef]

9. Kosmopoulos, P.G.; Kazadzis, S.; Taylor, M.; Athanasopoulou, E.; Speyer, O.; Raptis, P.I.; Marinou, E.; Proestakis, E.; Solomos, S.; Gerasopoulos, E.; et al. Dust impact on surface solar irradiance assessed with model simulations, satellite observations and ground-based measurements. Atmos. Meas. Tech. 2017, 10, 2435-2453. [CrossRef]

10. Gautam, R.; Hsu, N.C.; Lau, K.-M.; Yasunari, T.J. Satellite observations of desert dust-induced Himalayan snow darkening. Geophys. Res. Lett. 2013, 40, 988-993. [CrossRef]

11. Gherboudj, I.; Naseema Beegum, S.; Ghedira, H. Identifying natural dust source regions over the Middle-East and North-Africa: Estimation of dust emission potential. Earth-Sci. Rev. 2017, 165, 342-355. [CrossRef]

12. Hamidi, M.; Kavianpour, M.R.; Shao, Y. A quantitative evaluation of the 3-8 July 2009 Shamal dust storm. Aeolian Res. 2017, 24, 133-143. [CrossRef]

13. Dipu, S.; Prabha, T.V.; Pandithurai, G.; Dudhia, J.; Pfister, G.; Rajesh, K.; Goswami, B.N. Impact of elevated aerosol layer on the cloud microphysical properties prior to monsoon. Atmos. Environ. 2013, 70, 454-467. [CrossRef]

14. Rodríguez, S.; Cuevas, E.; Prospero, J.M.; Alastuey, A.; Querol, X.; López-Solano, J.; García, M.I.; Alonso-Pérez, S. Modulation of Saharan dust export by the North African dipole. Atmos. Chem. Phys. 2015, 15, 7471-7486. [CrossRef]

15. Mahowald, N.M.; Baker, A.R.; Bergametti, G.; Brooks, N.; Duce, R.A.; Jickells, T.D.; Kubilay, N.; Prospero, J.M.; Tegen, I. Atmospheric global dust cycle and iron inputs to the ocean. Glob. Biogeochem. Cycles 2005, 19. [CrossRef]

16. Lawrence, C.R.; Neff, J.C. The contemporary physical and chemical flux of aeolian dust: A synthesis of direct measurements of dust deposition. Chem. Geol. 2009, 267, 46-63. [CrossRef]

17. Nastos, P.T.; Kampanis, N.A.; Giaouzaki, K.N.; Matzarakis, A. Environmental impacts on human health during a Saharan dust episode at Crete Island, Greece. Meteorol. Z. 2011, 20, 517-529. [CrossRef]

18. Pérez García-Pando, C.; Stanton, M.C.; Diggle, P.J.; Trzaska, S.; Miller, R.L.; Perlwitz, J.P.; Baldasano, J.M.; Cuevas, E.; Ceccato, P.; Yaka, P.; et al. Soil Dust Aerosols and Wind as Predictors of Seasonal Meningitis Incidence in Niger. Environ. Health Perspect. 2014, 122, 679-686. [CrossRef]

19. Goudie, A.S. Desert dust and human health disorders. Environ. Int. 2014, 63, 101-113. [CrossRef]

20. Schepanski, K.; Mallet, M.; Heinold, B.; Ulrich, M. North African dust transport toward the western Mediterranean basin: Atmospheric controls on dust source activation and transport pathways during June-July 2013. Atmos. Chem. Phys. 2016, 16, 14147-14168. [CrossRef]

21. Yu, Y.; Notaro, M.; Kalashnikova, O.V.; Garay, M.J. Climatology of summer Shamal wind in the Middle East. J. Geophys. Res. 2016, 120. [CrossRef] 
22. Jish Prakash, P.; Stenchikov, G.; Kalenderski, S.; Osipov, S.; Bangalath, H. The impact of dust storms on the Arabian Peninsula and the Red Sea. Atmos. Chem. Phys. 2015, 15, 199-222. [CrossRef]

23. Kumar, R.; Barth, M.C.; Pfister, G.G.; Naja, M.; Brasseur, G.P. WRF-Chem simulations of a typical pre-monsoon dust storm in northern India: Influences on aerosol optical properties and radiation budget. Atmos. Chem. Phys. 2014, 14, 2431-2446. [CrossRef]

24. Beegum, S.N.; Gherboudj, I.; Chaouch, N.; Temimi, M.; Ghedira, H. Simulation and analysis of synoptic scale dust storms over the Arabian Peninsula. Atmos. Res. 2018, 199, 62-81. [CrossRef]

25. Mona, L.; Liu, Z.; Müller, D.; Omar, A.; Papayannis, A.; Pappalardo, G.; Sugimoto, N.; Vaughan, M. Lidar Measurements for Desert Dust Characterization: An Overview. Adv. Meteorol. 2012, 356265. [CrossRef]

26. Solomos, S.; Kalivitis, N.; Mihalopoulos, N.; Amiridis, V.; Kouvarakis, G.; Gkikas, A.; Binietoglou, I.; Tsekeri, A.; Kazadzis, S.; Kottas, M.; et al. From Tropospheric Folding to Khamsin and Foehn Winds: How Atmospheric Dynamics Advanced a Record-Breaking Dust Episode in Crete. Atmosphere 2018, 9, 240. [CrossRef]

27. Rezazadeh, M.; Irannejad, P.; Shao, Y. Climatology of the Middle East dust events. Aeolian Res. 2013, 10, 103-109. [CrossRef]

28. Rashki, A.; Arjmand, M.; Kaskaoutis, D.G. Assessment of dust activity and dust plume pathways over Jazmurian Basin, southeast Iran. Aeolian Res. 2017, 24, 145-160. [CrossRef]

29. Rashki, A.; Kaskaoutis, D.G.; Sepehr, A. Statistical evaluation of the dust events at selected stations in Southwest Asia: From the Caspian Sea to the Arabian Sea. Catena 2018, 165, 590-603. [CrossRef]

30. Francis, D.; Alshamsi, N.; Cuesta, J.; Isik, A.G.; Dundar, C. Cyclogenesis and density currents in the Middle East and the associated dust activity in September 2015. Geosciences 2019, 9, 376. [CrossRef]

31. Badarinath, K.V.S.; Kharol, S.K.; Kaskaoutis, D.G.; Sharma, A.R.; Ramaswamy, V.; Kambezidis, H.D. Long-range transport of dust aerosols over the Arabian sea and indian region: A case study using satellite data and ground-based measurements. Glob. Planet. Chang. 2010, 72, 164-181. [CrossRef]

32. Hermida, L.; Merino, A.; Sánchez, J.L.; Fernández-González, S.; García-Ortega, E.; López, L. Characterization of synoptic patterns causing dust outbreaks that affect the Arabian Peninsula. Atmos. Res. 2018, 199, $29-39$. [CrossRef]

33. Yu, Y.; Notaro, M.; Liu, Z.; Wang, F.; Alkolibi, F.; Fadda, E.; Bakhrjy, F. Climatic controls on the interannual to decadal variability in Saudi Arabian dust activity: Toward the development of a seasonal dust prediction model. J. Geophys. Res. 2015, 120, 1739-1758. [CrossRef]

34. Kaskaoutis, D.G.; Houssos, E.E.; Rashki, A.; Francois, P.; Legrand, M.; Goto, D.; Bartzokas, A.; Kambezidis, H.D.; Takemura, T. The Caspian Sea-Hindu Kush Index (CasHKI): A regulatory factor for dust activity over southwest Asia. Glob. Planet. Chang. 2016, 137, 10-23. [CrossRef]

35. Bou Karam Francis, D.; Flamant, C.; Chaboureau, J.-P.; Banks, J.; Cuesta, J.; Brindley, H.; Oolman, L. Dust emission and transport over Iraq associated with the summer Shamal winds. Aeolian Res. 2017, 24, $15-31$. [CrossRef]

36. Jin, Q.; Wei, J.; Pu, B.; Yang, Z.-L.; Parajuli, S.P. High summertime aerosol loadings over the Arabian Sea and their transport pathways. J. Geophys. Res. 2018, 123, 10568-10590. [CrossRef]

37. Todd, M.C.; Washington, R.; Raghavan, S.; Lizcano, G.; Knippertz, P. Regional model simulations of the Bodélé low-level jet of northern Chad during the Bodélé Dust Experiment (BoDEx 2005). J. Clim. 2008, 21, 995-1012. [CrossRef]

38. Kaskaoutis, D.G.; Rashki, A.; Houssos, E.E.; Mofidi, A.; Goto, D.; Bartzokas, A.; Francois, P.; Legrand, M. Meteorological aspects associated with dust storms in the Sistan region, southeastern Iran. Clim. Dynam. 2015, 45, 407-424. [CrossRef]

39. Knippertz, P.; Deutscher, C.; Kandler, K.; Müller, T.; Schulz, O.; Schütz, L. Dust mobilization due to density currents in the Atlas region: Observations from the SAMUM 2006 field campaign. J. Geophys. Res. 2007, 112, D21109. [CrossRef]

40. Knippertz, P.; Trentmann, J.; Seifert, A. High resolution simulations of convective cold pools over the northwestern Sahara. J. Geophys. Res. 2009, 114, D21109. [CrossRef]

41. Bou Karam, D.; Williams, E.; Janiga, M.; Flamant, C.; McGraw-Herdeg, M.; Cuesta, J.; Auby, A.; Thorncroft, C. Synoptic scale dust emissions over the Sahara desert initiated by a moist convective cold pool in early August 2006. Q. J. R. Meteorol. Soc. 2014, 140, 2591-2607. [CrossRef] 
42. Alizadeh Choobari, O.; Zawar-Reza, P.; Sturman, A. Low level jet intensification by mineral dust aerosols. Ann. Geophys. 2013, 31, 625-632. [CrossRef]

43. Saeedi, A.; Khoshakhlagh, F. A composite analysis of the morning cyclone in two Asian deserts. Theor. Appl. Climatol. 2018. [CrossRef]

44. Rashki, A.; Kaskaoutis, D.G.; Eriksson, P.G.; Qiang, M.; Gupta, P. Dust storms and their horizontal dust loading in the Sistan region, Iran. Aeolian Res. 2012, 5, 51-62. [CrossRef]

45. Alizadeh Choobari, O.; Zawar-Reza, P.; Sturman, A. The "wind of 120 days" and dust storm activity over the Sistan Basin. Atmos. Res. 2014, 143, 328-341. [CrossRef]

46. Middleton, N.J. Variability and Trends in Dust Storm Frequency on Decadal Timescales: Climatic Drivers and Human Impacts. Geosciences 2019, 9, 261. [CrossRef]

47. Miri, A.; Ahmadi, H.; Ekhtesasi, M.R.; Panjehkeh, N.; Ghanbari, A. Environmental and socio-economic impacts of dust storms in Sistan Region, Iran. Int. J. Environ. Stud. 2009, 66, 343-355. [CrossRef]

48. Ghaljahi, M.; Bagheri, S.; Keykhaei, K.R. The Effects of Haze on General Health of Women Employed in Zabol University of Medical Sciences in 2018. Asian J. Water Environ. Pollut. 2019, 16, 59-64. [CrossRef]

49. Rashki, A.; Kaskaoutis, D.G.; Goudie, A.S.; Kahn, R.A. Dryness of ephemeral lakes and consequences for dust activity: The case of the Hamoun drainage basin, southeastern Iran. Sci. Total Environ. 2013, 463, 552-564. [CrossRef]

50. Kaskaoutis, D.G.; Houssos, E.E.; Minvielle, F.; Rashki, A.; Chiapello, I.; Dumka, U.C.; Legrand, M. Long-term variability and trends in the Caspian Sea-Hindu Kush Index: Influence on atmospheric circulation patterns, temperature and rainfall over the Middle East and southwest Asia. Glob. Planet. Chang. 2018, 169, 16-33. [CrossRef]

51. Behrooz, R.D.; Esmaili-Sari, A.; Bahramifar, N.; Kaskaoutis, D.G. Analysis of the TSP, PM10 concentrations and water-soluble ionic species in airborne samples over Sistan, Iran during the summer dusty period. Atmos. Pollut. Res. 2017, 8, 403-417. [CrossRef]

52. Behrooz, R.D.; Esmaili-Sari, A.; Bahramifar, N.; Kaskaoutis, D.G.; Saeb, K.; Rajaei, F. Trace-element concentrations and water-soluble ions in size-segregated dustborne and soil samples in Sistan, southeast Iran. Aeolian Res. 2017, 25, 87-105. [CrossRef]

53. Sharifikia, M. Environmental challenges and drought hazard assessment of Hamoun Desert Lake in Sistan region, Iran, based on the time series of satellite imagery. Nat. Hazards 2013, 65, 201-217. [CrossRef]

54. Behrooz, R.D.; Gholami, H.; Telfer, M.W.; Jansen, J.D.; Fathabadi, A. Using GLUE to pull apart the provenance of atmospheric dust. Aeolian Res. 2019, 37, 1-13. [CrossRef]

55. Alam, K.; Trautmann, T.; Blaschke, T. Aerosol optical properties and radiative forcing over mega-city Karachi. Atmos. Res. 2011, 101, 773-782. [CrossRef]

56. Kaskaoutis, D.G.; Rashki, A.; Houssos, E.E.; Goto, D.; Nastos, P.T. Extremely high aerosol loading over Arabian Sea during June 2008: The specific role of the atmospheric dynamics and Sistan dust storms. Atmos. Environ. 2014, 94, 374-384. [CrossRef]

57. Rashki, A.; Kaskaoutis, D.G.; Francois, P.; Kosmopoulos, P.G.; Legrand, M. Dust-storm dynamics over Sistan region, Iran: Seasonality, transport characteristics and affected areas. Aeolian Res. 2015, 16, 35-48. [CrossRef]

58. Evenstar, L.A.; Sparks, R.S.J.; Cooper, F.J.; Lawton, M.N. Quaternary landscape evolution of the Helmand Basin, Afghanistan: Insights from staircase terraces, deltas, and paleoshorelines using high-resolution remote sensing analysis. Geomorphology 2018, 311, 37-50. [CrossRef]

59. Abbasi, H.; Opp, C.; Groll, M.; Gohardoust, A. Wind regime and sand transport in the Sistan and Registan regions (Iran/Afghanistan). Z. Geomorphol. 2019, 62, 41-57. [CrossRef]

60. Rashki, A.; Eriksson, P.G.; Rautenbach, C.J.W.; Kaskaoutis, D.G.; Grote, W.; Dykstra, J. Assessment of chemical and mineralogical characteristics of airborne dust in the Sistan region, Iran. Chemosphere 2013, 90, 227-236. [CrossRef]

61. Hamzeh, M.A.; Gharaie, M.H.M.; Lahijani, H.A.K.; Djamali, M.; Harami, R.M.; Beni, A.N. Holocene hydrological changes in SE Iran, a key region between Indian Summer Monsoon and Mediterranean winter precipitation zones, as revealed from a lacustrine sequence from Lake Hamoun. Quat. Int. 2016. [CrossRef]

62. Saeed, T.M.; Al-Dashti, H.; Spyrou, C. Aerosol's optical and physical characteristics and direct radiative forcing during a shamal dust storm, a case study. Atmos. Chem. Phys. 2014, 14, 3751-3769. [CrossRef] 
63. Dee, D.P.; Uppala, S.M.; Simmons, A.J.; Berrisford, P.; Poli, P.; Kobayashi, S.; Andrae, U.; Balmaseda, M.A.; Balsamo, G.; Bauer, P.; et al. The ERA-Interim reanalysis: Configuration and performance of the data assimilation system. Q. J. R. Meteorol. Soc. 2011, 137, 553-597. [CrossRef]

64. Banks, J.R.; Hünerbein, A.; Heinold, B.; Brindley, H.E.; Deneke, H.; Schepanski, K. The sensitivity of the colour of dust in MSG-SEVIRI Desert Dust infrared composite imagery to surface and atmospheric conditions. Atmos. Chem. Phys. 2019, 19, 6893-6911. [CrossRef]

65. Yue, H.; He, C.; Zhao, Y.; Ma, Q.; Zhang, Q. The brightness temperature adjusted dust index: An improved approach to detect dust storms using MODIS imagery. Intern. J. Appl. Earth Observ. Geoinform. 2017, 57, 166-176. [CrossRef]

66. Baddock, M.C.; Bullard, J.E.; Bryant, R.G. Dust source identification using MODIS: A comparison of techniques applied to the Lake Eyre Basin, Australia. Remote Sens. Environ. 2009, 113, 1511-1528. [CrossRef]

67. Zheng, X.; Lu, W.; Jingning, L. Research on The dust storm monitoring using multi-channel meteorological satellite data. Chin. J. Remote Sens. 2001, 5, 300-305.

68. Lafore, J.P.; Stein, N.; Asencio, J.; Bougeault, P.; Ducrocq, V.; Duron, J.; Fischer, C.; Hereil, P.; Mascart, P.; Pinty, J.P.; et al. The Meso-NH Atmospheric Simulation System. Part I: Adiabatic formulation and control simulations. Scientific objectives and experimental design. Ann. Geophys. 1998, 16, 90-109. [CrossRef]

69. Lac, C.; Chaboureau, J.-P.; Masson, V.; Pinty, P.; Tulet, P.; Escobar, J.; Leriche, M.; Barthe, C.; Aouizerats, B.; Augros, C.; et al. Overview of the Meso-NH model version 5.4 and its applications. Geosci. Model Dev. 2018, 11, 1929-1969. [CrossRef]

70. Grini, A.; Tulet, P.; Gomes, L. Dusty weather forecasts using the MesoNH mesoscale atmospheric model. J. Geophys. Res. 2006, 111, D19205. [CrossRef]

71. Bou Karam, D.; Flamant, C.; Knippertz, P.; Reitebuch, O.; Pelon, J.; Chong, M.; Dabas, A. Dust emissions over the Sahel associated with the West African Monsoon inter-tropical discontinuity region: A representative case study. Q. J. R. Meteorol. Soc. 2008, 134, 621-634. [CrossRef]

72. Bou Karam, D.; Flamant, C.; Cuesta, J.; Pelon, J.; Williams, E. Dust emission and transport associated with a Saharan depression: The February 2007 case. J. Geophys. Res. 2010. [CrossRef]

73. Chaboureau, J.-P.; Richard, E.; Pinty, J.-P.; Flamant, C.; Di Girolamo, P.; Kiemle, C.; Behrendt, A.; Chepfer, H.; Chiriaco, M.; Wulfmeyer, V. Long-range transport of Saharan dust and its radiative impact on precipitation forecast over Western Europe: A case study during the Convective and Orographically induced Precipitation Study (COPS). Q. J. R. Meteorol. Soc. 2011, 137, 236-251. [CrossRef]

74. Bou Karam, D.; Flamant, C.; Knippertz, P.; Reitebuch, O.; Pelon, J.; Chong, M.; Dabas, A. Dry cyclogenesis and dust mobilization in the Inter Tropical Discontinuity of the West African Monsoon: A case study. J. Geophys. Res. 2009, 114, D05115. [CrossRef]

75. Bou Karam, D.; Flamant, C.; Tulet, P.; Chaboureau, J.-P.; Dabas, A.; Todd, M.C. Estimate of Sahelian dust emissions in the inter-tropical discontinuity region of the West African Monsoon. J. Geophys. Res. 2009, 114, D13106. [CrossRef]

76. Chaboureau, J.-P.; Flamant, C.; Dauhut, T.; Kocha, C.; Lafore, J.P.; Lavaysse, C.; Marnas, F.; Mokhtari, M.; Pelon, J.; Martínez, I.R.; et al. Fennec dust forecast intercomparison over the Sahara in June 2011. Atmos. Chem. Phys. 2016, 16, 6977-6995. [CrossRef]

77. Mlawer, E.J.; Taubman, S.J.; Brown, P.D.; Iacono, M.J.; CLough, S.A. Radiative transfer for inhomogeneous atmospheres: RRTM, a validated correlated-k model for the longwave. J. Geophys. Res. 1997, 102D, 16663-16682. [CrossRef]

78. Pinty, J.-P.; Jabouille, P. A mixed-phase cloud parameterization for use in a mesoscale non-hydrostatic model: Simulations of a squall line and of orographic precipitations. In Conference on Cloud Physics; American Meteorological Society: Everett, WA, USA, 1998; pp. 217-220.

79. Cuxart, J.; Bougeault, P.; Redelsperger, J.L. A turbulence scheme allowing for mesoscale and large-eddy simulations. Q. J. R. Meteorol. Soc. 2000, 126, 1-30. [CrossRef]

80. Bechtold, P.; Bazile, E.; Guichard, F.; Mascart, P.; Richard, E. A mass flux convection scheme for regional and global models. Q. J. R. Meteorol. Soc. 2001, 127, 869-886. [CrossRef]

81. Chaboureau, J.-P.; Bechtold, P. Statistical representation of clouds in a regional model and the impact on the diurnal cycle of convection during Tropical Convection, Cirrus and Nitrogen Oxides (TROCCINOX). J. Geophys. Res. 2005, 110, D17103. [CrossRef] 
82. Zender, C.S.; Bian, H.S.; Newman, D. Mineral Dust Entrainment and Deposition (DEAD) model: Description and 1990s dust climatology. J. Geophys. Res. 2003, 108, 4416. [CrossRef]

83. Tulet, P.; Crassier, V.; Cousin, F.; Shure, K.; Rosset, R. ORILAM, A three moment lognormal aerosol scheme for mesoscale atmospheric model. On-line coupling into the Meso-NH-C model and validation on the Escompte campaign. J. Geophys. Res. 2005, 110, D18201. [CrossRef]

84. Orlovsky, L.; Orlovsky, N.; Durdyev, A. Dust storms in Turkmenistan. J. Arid Environ. 2005, 60, 83-97. [CrossRef]

85. Kaskaoutis, D.G.; Rashki, A.; Francois, P.; Dumka, U.C.; Houssos, E.E.; Legrand, M. Meteorological regimes modulating dust outbreaks in southwest Asia: The role of pressure anomaly and Inter-Tropical Convergence Zone on the 1-3 July 2014 case. Aeolian Res. 2015, 18, 83-97. [CrossRef]

86. Rashki, A.; Kaskaoutis, D.G.; Mofidi, A.; Minvielle, F.; Chiapello, I.; Legrand, M.; Dumka, U.C.; Francois, P. Effects of Monsoon, Shamal and Levar winds on dust accumulation over the Arabian Sea during summer-The July 2016 case. Aeolian Res. 2019, 36, 27-44. [CrossRef]

87. Favre, A.; Hewitson, B.; Lennard, C.; Cerezo-Mota, R.; Tadros, M. Cut-off Lows in the South Africa region and their contribution to precipitation. Clim. Dynam. 2012, 41, 2331-2351. [CrossRef]

88. Gimeno, L.; Trigo, R.M.; Ribera, P.; Garcia, J.A. Editorial: Special issue on cut-off low systems (COL). Meteorol. Atmos. Phys. 2007, 96, 1-2. [CrossRef]

89. Nieto, R.; Sprenger, M.; Wernli, H.; Trigo, R.M.; Gimeno, L. Identification and Climatology of Cut-off Lows near the Tropopause. Trends Dir. Clim. Res. 2008, 1146, 256-290. [CrossRef]

90. Francis, D.; Eayrs, C.; Chaboureau, J.-P.; Mote, T.; Holland, D. Polar jet associated circulation triggered a Saharan cyclone and derived the poleward transport of the African dust generated by the cyclone. J. Geophys. Res. 2018. [CrossRef]

91. Solomos, S.; Kallos, G.; Mavromatidis, E.; Kushta, J. Density currents as a desert dust mobilization mechanism. Atmos. Chem. Phys. 2012, 12, 11199-11211. [CrossRef]

92. Maghrabi, A.; Alharbi, B.; Tapper, N. Impact of the March 2009 dust event in Saudi Arabia on aerosol optical properties, meteorological parameters, sky temperature and emissivity. Atmos. Environ. 2011, 45, $2164-2173$. [CrossRef]

93. Alharbi, B.H.; Maghrabi, A.; Tapper, N. The March 2009 dust event in Saudi Arabia: Precursor and supportive environment. Bull. Am. Meteorol. Soc. 2013, 94, 515-528. [CrossRef]

94. Middleton, N.J.; Kang, U. Sand and Dust Storms: Impact Mitigation. Sustainability 2017, 9, 1053. [CrossRef]

95. Fiedler, S.; Schepanski, K.; Heinold, B.; Knippertz, P.; Tegen, I. How important are atmospheric depressions and mobile cyclones for emitting mineral dust aerosol in North Africa? Atmos. Chem. Phys. 2014, 14, 8983-9000. [CrossRef]

96. Kaskaoutis, D.G.; Dumka,U.C.; Rashki, A.; Psiloglou, B.E.; Gavriil, A.; Mofidi, A.; Petrinoli, K.; Karagiannis, D.; Kambezidis, H.D. Analysis of intense dust storms over the eastern Mediterranean in March 2018: Impact on radiative forcing and Athens air quality. Atmos. Environ. 2019, 209, 23-39. [CrossRef]

97. Pokharel, A.K.; Kaplan, M.L.; Fiedler, S. Subtropical dust storms and downslope wind events. J. Geophys. Res. 2017, 122, 10191-10205. [CrossRef]

98. Singh, R.P.; Prasad, A.K.; Kayetha, V.K.; Kafatos, M. Enhancement of oceanic parameters associated with dust storms using satellite data. J. Geophys. Res. 2008, 113, C11008. [CrossRef]

99. Richon, C.; Dutay, J.-C.; Dulac, F.; Wang, R.; Balkanski, Y. Modeling the biogeochemical impact of atmospheric phosphate deposition from desert dust and combustion sources to the Mediterranean Sea. Biogeosciences 2018, 15, 2499-2524. [CrossRef]

100. Solmon, F.; Nair, V.S.; Mallet, M. Increasing Arabian dust activity and the Indian Summer Monsoon. Atmos. Chem. Phys. 2015, 15, 8051-8064. [CrossRef]

101. Jin, Q.; Yang, Z.-L.; Wei, J. Seasonal responses of Indian summer monsoon to dust aerosols in the Middle East, India, and China. J. Clim. 2016, 29, 6329-6349. [CrossRef]

(C) 2019 by the authors. Licensee MDPI, Basel, Switzerland. This article is an open access article distributed under the terms and conditions of the Creative Commons Attribution (CC BY) license (http://creativecommons.org/licenses/by/4.0/). 